\title{
Reemployment Experiences of Displaced Workers and The Impacts of the Canadian Earnings Supplement Project
}

\author{
Suk-Won Lee*
}

\begin{abstract}
The Canadian Earnings Supplement Project (ESP) was conducted from 1994 through 1996 to test a wage subsidy program that made supplemental payments to individuals who found a new full-time job that paid less than their previous job within 26 weeks of job search. Contrary to the optimistic expectations held by researchers and previous studies, the impact of ESP was disappointing. This paper attempts to uncover the reasons why ESP did not have sufficient impact by analyzing the reemployment experiences of ESP participants. I found that the insufficient impacts of ESP could be attributed to the fact that a significant proportion (65 percent) of sample members set initial reservation wages lower than their previous wages. Workers who enjoyed wage premiums in their previous jobs (whether job-specific, industry-specific, or union-specific premiums) were found to have low initial reservation wages. In contrast, workers with high education credentials, white-collar workers, and workers in knowledge-based industries appeared to be not interested in the ESP offer, becausc they expected no earnings loss and thus no gain in lifetime wealth from receipt of the supplement. To be discordant with the propositions made by past theoretical works on wage subsidy programs, job-search intensity was not the major link through which ESP impacts were channeled. Another important finding is that ESP manifested a significantly large impact on the optimal timing of leaving unemployment, even though its impact on the overall probability of leaving unemployment was minuscule.
\end{abstract}

\section{INTRODUCTION}

In many countries including US and Canada, the unemployment insurance (UI) system is probably the most basic program that assists displaced workers. UI provides partial replacement for the earnings loss that displaced workers experience while unemployed.1) However, UI system is essentially confronted with a fundamental trade-off between adequate income security and work disincentives. It is well established in welfare economics that social assistance programs generate disincentives to work. Some argue that a more generous UI benefit level (i.e. larger UI benefit amount and longer UI benefit duration) would generate a serious work disincentive, leading to

\footnotetext{
* Professor, Seoul National University
}

1) In Canada in 1995, workers who lost an insured job received UI benefit payments equal to $55 \%$ of prior earnings, up to a maximum weekly benefit of $\$ 448$ (Bloom et al., 1997). prolonged unemployment and an increase in steady-state overall unemployment rate. Another limit of the UI system, in addition to work disincentives, is its insufficiency to compensate displaced workers' earnings loss, which has been recognized as one of the most serious and pervasive problem that displaced workers experience. UI replaces only a small portion of earnings loss, about $50 \%{ }^{2}$ ) of previous insurable earnings. Moreover, a significant number of unemployed do not file UI claims.

An array of other policy alternatives were suggested and tested to address the work disincentives of UI system and the earnings loss of displaced workers, including intensive job-search assistance, occupational skills training programs, ${ }^{3)}$ self-

2) In the United States, benefit ratios are usually less than $50 \%$ and vary among states. In Canada, it was $55 \%$ in 1995.

3) According to Bloom, Schwartz, Lui-Gurr, and Lee (1999), job-search assistance has been found to be a costeffective way to promote reemployment, but the occupa- 
employment assistance, extended UI benefits under the Trade Adjustment Assistance (TAA) Program, and federally mandated advance-notice requirements. Although some of these were effective in expediting the reemployment process, none provided comprehensive compensation for earnings loss. For this and other reasons, a new policy design is called for that directly subsidizes the whole or partial amount of earnings losses that displaced workers incur.

The Earnings Supplement Project (ESP) was conducted in response to this social need. ESP was a randomized experiment conducted at five Canadian sites from 1994 through 1996. Its purpose was to test an earnings subsidy program providing supplemental payments to individuals who had found a new full-time job within 26 weeks of their job search but that paid less than the previous job. One impetus for launching such an experiment was the promise held by a fair number of theoretical and empirical researchers (e.g., Davidson \& Woodbury, 1994; Jacobson, LaLonde, \& Sullivan, 1993) as to the potential impact of an earnings subsidy program. Contrary to expectations, however, the experimental findings were rather disappointing. Interestingly, the supplement paid by ESP was considered more generous than most other existing programs. Then, why, given the generous payment and the promising results predicted by many researchers, did ESP have such an unexpectedly small impact? This paper was built upon that fundamental question. Based on this fundamental question, I attempted to answer the following research questions in this paper.

- What factors influenced the determination of reservation wage, job search effort, reemployment wage and unemployment duration?

- How, if at all, did ESP affect those outcome variables?

- Given the findings from the preceding questions,

tional skills training program has not. why did ESP have such a small impact on the reemployment outcomes?

- What are the suggestions and implications for policy makers?

The first section of this paper describes the experimental evaluation of Earnings Supplement Project. The second section presents the theoretical framework adapted to pursue the above research questions. The third section explains the strategy for empirical analysis and the next section discuss the empirical results. The fourth section presents empirical findings and the final section discusses the policy implications of the findings and concludes this paper.

\section{THE EARNINGS SUPPLEMENT PROJECT}

Although many researchers have suggested a need for an earnings subsidy program, no experimental study of such a program has been conducted in the United States. However, the Earnings Supplement Project (ESP), was launched in Canada in 1994, the first experimental study to test the effectiveness of the earnings subsidy system. The ESP was initiated by Human Resources Development Canada (HRDC), and conducted by the Social Research Demonstration Corporation (SRDC), a Canadian nonprofit research organization. Between 1995 and 1996, iIn five Human Resource Centres Canada (HRCCs) Granby, Oshawa, Toronto, Winnipeg, and Saskatoon-8,144 displaced workers were randomly assigned to either a program group or a control group, and they were followed up for 15 months thereafter. ${ }^{4}$ ) Those assigned to the program group were offered an earnings supplement that paid $75 \%$ of earnings losses, if they found a new

4) Although, the original SRDC study was conducted in nine HRCCs, this paper is based on the "ESP displaced worker study" that was conducted in five HRCCs. 
full-time job within 26 weeks that paid less than their previous weekly UI insurable earnings.

Experimental findings on supplement receipt, impacts, and cost-benefit of ESP are presented in Bloom et al. (1999). Bloom et al. (1997; 1999) initially expected ESP to have a considerable impact on labor-market outcomes. Their positive expectations were based on two factors. The first relates to the fact that ESP is designed to influence displaced workers' behavior. Many displaced workers may have an unrealistically high reservation wage (especially for long-tenured workers) and thus will stay unemployed as they seek a better-paying job. Providing them with a supplement will allow them to set up a new strategy. Those with a supplement offer can take a lower-paying job, which they would have otherwise rejected, to begin the earnings gain process earlier. The second factor relates to the generosity of the program. According to Bloom et al. (1999), ESP was far more generous in many regards than the UI reemployment bonuses that had been tested in the US. ESP paid a supplement immediately after displaced workers gained reemployment and continued up to two years after the supplement offer, whereas most of the UI bonus programs paid only after four4 months of continual employment. ESP allowed a longer job-search period, 26 weeks, rather than 3 to 13 weeks for the UI bonuses. More importantly, ESP provided much larger payments, averaging $\$ 8,705$ per recipient, instead of $\$ 500$ to $\$ 1,664$ per UI bonus recipient. These generous features of ESP reinforced the belief that ESP would have a larger impact than other existing programs that had been tested.

However, it turned out to be quite the contrary. Bloom et al. (1999) presented the 15-month experimental findings for ESP. Table 1 summarizes these findings. As shown, ESP had a small positive impact on the full-time employment rate and almost no impact on other outcomes, such as job search or UI benefit duration and amount. ESP increased the percentage of displaced workers who became re-employed full-time during the 26-week jobsearch period by $4.4 \%$ points. This increase was achieved by lowering displaced workers' average earnings for 15 months by $\$ 682$ (or $4.6 \%$ ) or the hourly wage rate by $\$ 0.3$ (or $2.5 \%$ ).5) Quite unexpectedly, ESP had almost no impact on the job-search behavior of program group members. In most ways, program group members and control group members showed similar job-search behavior except that program group members were slightly more likely (by $2.1 \%$ ) to consider new types of jobs. ESP did not have any impact on UI benefit amount or its duration. Bloom et al.'s (1999) findings also indicated no particularly large impacts for any subgroup, but only a modest impacts for full-time reemployment.

The only significant impact on full-time reemployment was short-lived and was not enough to fully validate ESP as a policy alternative for assisting displaced workers in a cost-effective manner.

Their study also showed that participants' lack of knowledge about ESP was not a cause for its minimal impact. Rather, it turned out that the information about ESP was offered in a wellorganized manner, and participants were generally aware of the features of the supplement offer.

\section{THEORETICAL FRAMEWORK}

In uncovering the reasons behind ESP's small impact, it is crucial first to understand the behavioral process that displaced workers go through from the time of displacement to the time of reemployment. When workers are laid off from a job, they set a certain asking price (i.e., reservation wage) for the provision of their labor and then begin to search for a job that pays a wage exceeding or at least equal to their asking price. As they

5) It should be noted that these figures are not statistically significant. 
Table 1. Summary of Findings for ESP Impacts

\begin{tabular}{|c|c|c|c|}
\hline & Program Group & Control Group & Impact \\
\hline $\begin{array}{l}\text { Supplement Receipt } \\
\text { Percentage who qualified for supplement payments } \\
\text { Percentage who received supplement payments } \\
\text { Average 24-month supplement payments per recipient } \\
\text { Average } 15 \text {-month supplement payments per program group member } \\
\text { Percentage who qualified for earnings insurance } \\
\text { Percentage who initiated earnings insurance }\end{array}$ & $\begin{array}{l}26.8 \% \\
20.5 \% \\
\$ 8,705 \\
\$ 1,161 \\
11.9 \% \\
0.2 \%\end{array}$ & $\begin{array}{l}\text { na } \\
\text { na } \\
\text { na } \\
\text { na } \\
\text { na } \\
\text { na }\end{array}$ & $\begin{array}{l}\mathrm{Na} \\
\mathrm{Na} \\
\mathrm{Na} \\
\mathrm{Na} \\
\mathrm{Na} \\
\mathrm{Na}\end{array}$ \\
\hline $\begin{array}{l}\text { Impacts } \\
\text { Percentage employed full-time within six months of random assignment } \\
\text { Average total earnings during the first } 15 \text { months after random assignment } \\
\text { Average } 15 \text { month hourly earnings } \\
\text { Average weeks of unemployment benefits during the first } 15 \text { months } \\
\text { after random assignment } \\
\text { Average total amount of unemployment benefits during the first } \\
15 \text { months after random assignment }\end{array}$ & $\begin{array}{c}42.3 \% \\
\$ 14,209 \\
\$ 12.67 \\
22.1 \text { weeks } \\
\$ 6,460\end{array}$ & $\begin{array}{c}37.9 \% \\
\$ 14,891 \\
\$ 13.00 \\
21.9 \text { weeks } \\
\$ 6,370\end{array}$ & $\begin{array}{c}4.4 \% * * * \\
-\$ 682 \\
-\$ 0.33^{*} \\
0.1 \text { weeks } \\
\$ 90\end{array}$ \\
\hline $\begin{array}{l}\text { Financial Implications } \\
\text { Net financial benefits per program group member during the first } \\
15 \text { months after random assignment } \\
\text { Net government costs per program group member during the first } \\
15 \text { months after random assignment }\end{array}$ & $\begin{array}{c}\$ 569 \\
\$ 1,340\end{array}$ & $\begin{array}{l}\text { na } \\
\text { na }\end{array}$ & $\begin{array}{l}\mathrm{Na} \\
\mathrm{Na}\end{array}$ \\
\hline $\begin{array}{l}\text { Statistically significant at the } 0.10 \text { level for a two-tail test; }{ }^{* *} \text { significant at the } 0 . \\
\text { Note: This table is adapted from Table } 9.3 \text { on p.83 of Bloom et al. (1999) }\end{array}$ & .05 level; $\quad$ s1 & . & \\
\hline
\end{tabular}
job quickly. Consequently, they may adjust their asking price to a lower level and/or increase their search activity. In order to examine this process in a theoretical framework, I borrowed 'job-search theory' that has been developed in the filed of labor economics.

Job search theory is a major theoretical tool that explains displaced workers' decision to search for jobs and leave unemployment. Job search theory assumes that an individual with imperfect information searches for a job and accepts the first job offer that exceeds his or her reservation wage. How the level of search effort and reservation wage is decided can be illustrated by the following equation (1).

Where $r=$ individual's discount rate, $x=$ given wage offer, $s=$ the individual's search effort, $\Theta=$ potential wage offer arrival rate, $R W(t)=$ reservation wage (as a function of time, $t$ ), and $F(\cdot)=$ Cumulative Distribution Function (c.d.f) of wage offers. $c(s)=$ out-of-pocket cost of job-search, $V_{s}(S)$ $=$ value of the time spent on the search, and $V_{l}=$ value of the time spent as leisure.

Equation (1) shows that optimal search effort $(s)$ is determined where the marginal cost of the search equals the marginal benefit of the search. Intuitively, one would increase search effort as the value of being employed increases. ${ }^{6}$ In this framework, a

6) ESP would increases the value of being employed by reducing expected earnings loss. 
worker would increase the search effort to shorten the expected time period in which to find an acceptable job, thereby increase the marginal benefit from the search (Mortensen, 1986). If an earnings supplement is offered to a worker, he or she is expected to increase search effort to become eligible for the supplement by finding an eligible job within a specified eligibility period. Similarly, the reservation wage is decided by the equality between the value of being employed and the cost of being unemployed, implying that the reservation wage will be decreased if an earnings supplement is offered.

Based on the formal job-search theory, I developed an ESP impact model that attempts to translate conceptual ideas regarding the intervention of ESP and the expected consequences into hypothetical relationships through which ESP exerts its impact. The basic structure of the ESP impact model is represented by the causal relationships among the ESP supplement, two intervening outcomes (i.e., reservation wages and job-search effort), and two final outcomes (i.e., unemployment duration and reemployment wages). Figure 1 illustrates these relationships. Causal paths depicted in bold arrow lines (solid or dotted) indicate the main channel through which ESP delivers its impact.

How ESP affects the intervening outcomes, and how do the intervening outcomes affect the final outcomes can be explicated as follows:. First, as shown in Figure 1, ESP is expected to increase displaced workers' future earnings stream by compensating for a part of the earnings loss that they expect to incur. Then, the increase in the prospect of earnings stream would increase the value of being employed (or, equivalently, the opportunity cost of being unemployed) since they would lose the opportunity to earn higher income than can be

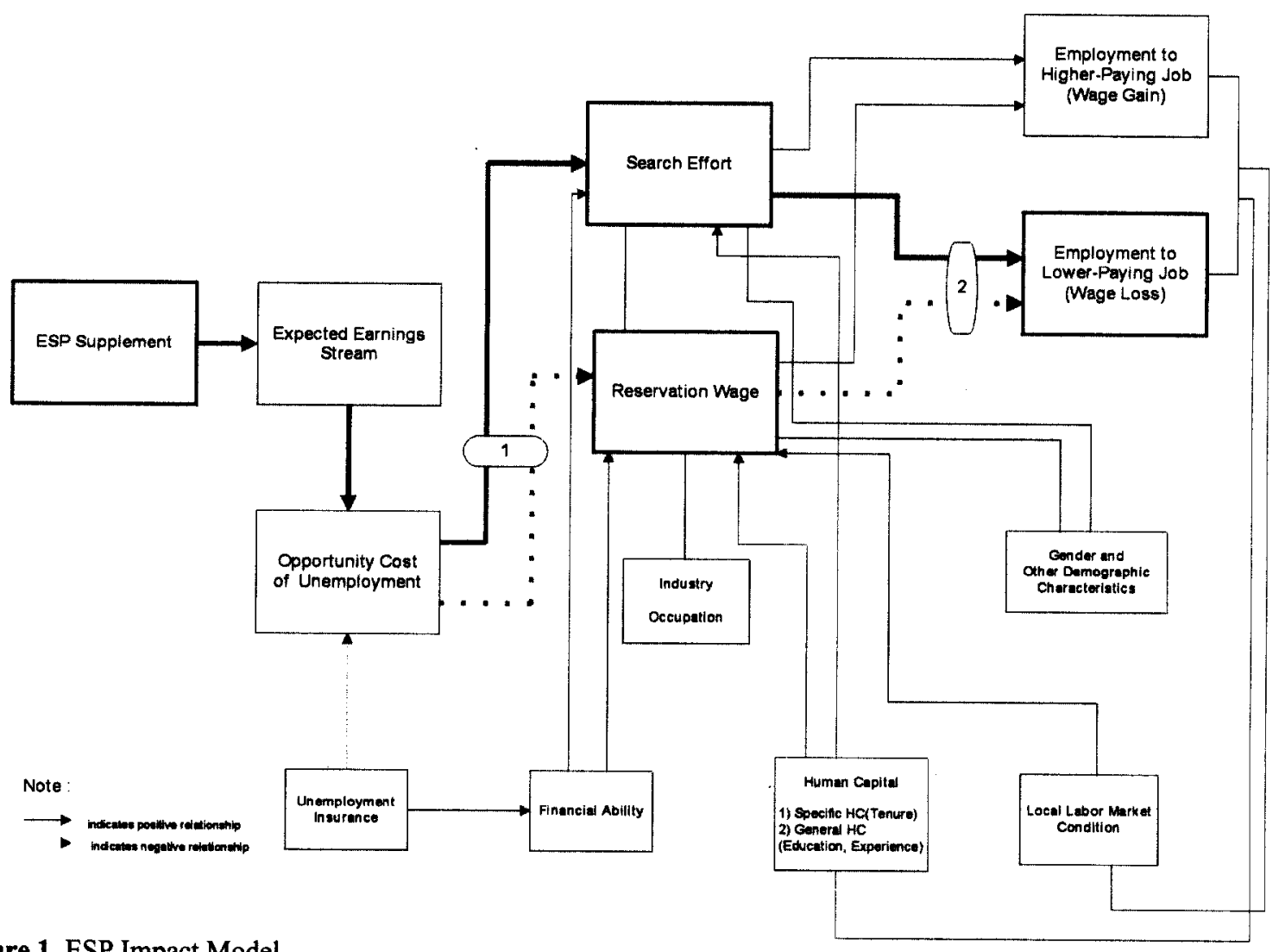

Figure 1. ESP Impact Model. 
earned without ESP as long as they remain unemployed (within the job-search time limit). Consequently, this will lead them to increase their job-search effort and to decrease reservation wages (path (1) in Figure 1). Both program and control group members will lower their reservation wages as unemployment duration progresses. However, program group members are expected to do so by more than control group members because ESP changes their expected future earnings stream. Both increased job-search effort and decreased reservation wages will make an individual find a lowerpaying job sooner than he or she would without ESP (path (2) in Figure 1). As a result, program members would experience shorter unemployment duration and larger earnings loss than would control group members.

\section{EMPIRICAL STRATEGY}

Based on the ESP impact model, I fit a series of reduced-form regression-type empirical equations, which analyze major outcome variables specified in the ESP impact model. I attend to outcome variables not explicitly analyzed in the experimental study but that carry important meaning in the reemployment process: (1) reservation wage, (2) job-search effort, (3) reemployment wage, and (4) unemployment duration. Recognizing reemployment wages and unemployment duration as final outcomes and recognizing reservation wages (and their changes over time) and job search effort as intermediate outcomes, as described below, I estimate the determinants of each outcome variable separately using different non-experimental methods to control for potential selection bias.

\section{Initial Reservation Wages and Job-Search Effort}

Initial Reservation Wage (IRW) is a reservation wage that displaced workers set at the time of displacement and before ESP was offered. Analyzing this outcome helps understand the underlying mechanism for prolonged unemployment duration or for the realization of ESP impacts. Ordinary Least Squares (OLS) was used to analyze the determinants of a ratio term of this outcome [takes the relative level of initial reservation wage with respect to previous wage (IRW ratio: $R W_{b} / W_{p}$ )].

For the analysis of an intervening outcome, jobsearch effort, I considered measures for two different types of job search effort;: job-search intensity and extensity. The intensity is measured as "the amount of time per week spent for job-search activity," and the extensity as "the number of employers per week a job seeker contacted in-person, by mail or by telephone." Unlike with the estimation of initial reservation wages, using OLS to estimate these variables may fail to produce a consistent estimator. The problem lies in that a significant fraction of sample members reported that they did engage in any kind of search activity or direct employer contact, and thus they reported their search hours or the number contacted firms as zero. In such a case, conventional OLS may fail to account for the qualitative difference between the "limit" observations (i.e., observations that have zero values) and non-limit observations (Greene, 1993). To deal with this problem, I used Tobit regression. Followings are the empirical model specifications for initial reservation wage, job search intensity, and job search extensity.

$$
\begin{aligned}
& \text { Initial Reservation Wage } \\
& \begin{aligned}
\ln \left(\frac{R W_{b}}{W_{p}}\right)_{i}= & \beta_{0}+\sum_{j} \beta_{1 j} U I_{j i}+\sum_{k} \beta_{2 k} F I N_{k i}(2) \\
& +\sum_{i} \beta_{3 l} I O_{l i}+\sum_{m} \beta_{4 m} H C_{m i} \\
& +\sum_{n} \beta_{5 n} X_{n i}+\sum_{0} \beta_{6 o} L M_{o i}+\varepsilon_{i}
\end{aligned}
\end{aligned}
$$


Search Intensity

$$
\begin{aligned}
T_{J S i}^{*}= & \beta_{0}+\beta_{1} \ln W_{p i}+\beta_{2} \ln \left(\frac{R W_{b i}}{W_{b i}}\right)+\sum_{j} \beta_{3 j} U I_{j i} \\
& +\sum_{k} \beta_{4 k} F I N_{k i}+\sum_{i} \beta_{5 l} I O_{l i}+\sum_{m} \beta_{6 m} H C_{m i} \\
& +\sum_{n} \beta_{7 n} X_{n i}+\sum_{o} \beta_{8 o} L M_{o i}+\sum_{b} \delta_{1 p} F H_{p i} \\
& +\sum_{q} \delta_{2 q} T R S R_{q i}+\alpha E S P_{i}
\end{aligned}
$$

\section{Search Extensity}

$$
\begin{aligned}
T_{J S i}^{*}= & \beta_{0}+\beta_{1} \ln W_{p i}+\beta_{2} \ln \left(\frac{R W_{b i}}{W_{p i}}\right)+\sum_{j} \beta_{3 j} U I_{j i} \\
& +\sum_{k} \beta_{4 k} F I N_{k i}+\sum_{l} \beta_{5 l} I O_{l i}+\sum_{m} \beta_{6 m} H C_{m i} \\
& +\sum_{n} \beta_{7 n} X_{m i}+\sum_{o} \beta_{8 o} L M_{o i}+\sum_{p} \delta_{l p} F H_{p i} \\
& +\sum_{q} \delta_{2 q} T R S R_{q i}+\alpha E S P_{i}
\end{aligned}
$$

where $U I=$ factors related with UI benefit level; $F I N=$ factors related with financial needs; $I O=$ factors related with industry and occupation; $H C=$ factors related with general and specific human capital; $X=$ various demographic and labor characteristics; and $L M=$ factors related with labor market conditions, $T_{J S}{ }^{*}=$ latent variable for the number of hours spent in job-search, $N_{J S}{ }^{*}=$ latent variable for the number of employers contacted by displaced workers, and $E S P=$ ESP program group dummy variable, $F H=$ financial hardship experience, and $T R S R=$ additional training or job-search assistance.

\section{Reemployment Wages}

As a final outcome of reemployment experience, I analyzed two ratio measures: Wage Replacement Ratio (WR Ratio: $W_{r} / W_{p}$ ) and Reservation Wage Replacement Ratio (RWR Ratio: $W_{r} / R W_{b}$ ). The WR ratio reflects the amount of earnings loss that workers experience as a consequence of displacement. The RWR ratio reflects the extent to which workers reduced their reservation wages during their unemployment period. In fact, the WR ratio is the product of the IRW ratio and the RWR ratio (i.e. $\frac{W_{r}}{W_{p}}=\frac{R W_{b}}{W_{p}} \times \frac{W_{r}}{R W_{b}}$ ). This implies that a wage loss is composed of two components: (1) $a$ loss from setting the initial reservation wage lower than previous wage (i.e. $\frac{R W_{b}}{W_{p}}$ ); and (2) a loss from accepting a wage offer that is lower than the initial reservation wage (i.e. $\frac{W_{r}}{R W_{b}}$ ). For a given wage offer rate, the latter component reflects the change of reservation wage over time after displacement.

In analyzing these outcome variables, a special concern arises because the outcome variables are available only for those who became reemployed after random assignment. Thus, conventional estimation leads to a selection problem: if reemployment wages are not independent of the process that determines the selection of the sample, this type of censored sample can lead to biased coefficient estimates. Even more complex problem arises because I focused on the probabilities that these ratio measures being less than 1. From a policy perspective, it may be more important to investigate what types of workers are more likely to experience a wage loss. By the same token, to understand the underlying mechanism of ESP impact, it is useful to investigate whether ESP sample members lowered their reservation wages from their initial level after they received a supplement. These tasks can be accomplished by estimating the probability of wage loss (i.e., $\left.\operatorname{Pr}\left(\frac{W_{r}}{W_{p}}<1\right)\right)$ and the probability of a reduction in reservation wages (i.e., $\operatorname{Pr}$ $\left.\left(\frac{W_{r}}{R W_{b}}<1\right)\right)$. In estimating these binary outcome variables, standard Heckman's two-stage procedure is not applicable because the model exposed to potential selection bias here has a binary dependent variable. Therefore, I use Bivariate Censored Probit model, which takes into account both the selection problem and the correlation between error terms by making use of the fact that three different types of probabilities actually exist in such a 
setting. This model estimates the following three unconditional probabilities with the log-likelihood function expressed in equation (6).

$$
\begin{aligned}
& \operatorname{Pr}(R E M=0)=1-\Phi\left(\beta_{3} X_{3}\right), \\
& \operatorname{Pr}(W L=0, R E M=1)=\Phi_{2}\left[-\beta_{4} X_{4}, \beta_{3} X_{3},-\rho\right], \\
& \operatorname{Pr}(W L=1, R E M=1)=\Phi_{2}\left[\beta_{4} X_{4}, \beta_{3} X_{3}, \rho\right]
\end{aligned}
$$

where $R E M=$ a dummy variable indicating whether an individual was reemployed; $W L=$ a dummy variable indicating whether an individual experienced a wage loss, and $\Phi_{2}=$ bivariate standard normal cumulative distribution function $[=\Phi(\cdot)$ $\Phi(\cdot)]$.

$$
\begin{aligned}
& \ln L\left(\beta_{3}, \beta_{4}, \rho\right)=\sum_{i=1}^{L}\left(R E M_{i} * W_{i}^{*}\right. \\
& \ln \Phi_{2}\left(\beta_{3} X_{3 i,} \beta_{4} X_{4 i,} \rho\right)+R E M_{i} *\left(1-W_{i}\right) * \\
& \ln \Phi_{2}\left(\beta_{3} X_{3 i}-\beta_{4} X_{4 i}-\rho\right)+\left(1-R E M_{i}\right) * \\
& \left.\quad \ln \left[1-\Phi\left(\beta_{3} X_{3 i}\right)\right]\right\}
\end{aligned}
$$

I specify empirical equations to estimate the wage loss and the reservation-wage reduction probabilities.

$$
\begin{aligned}
& P_{R W L i}=\Phi\left[\beta_{0}+\beta_{1} \ln W_{p i}+\delta_{1} I R W L l_{i}\right. \\
& \quad+\delta_{2} S P L L 6_{i}+\delta_{3} N J S_{i}+\delta_{4}\left(\operatorname{IRWL} l_{i} * E S P_{i}\right) \\
& \quad+\delta_{5}\left(S P L L 6_{i} * E S P_{i}\right)+\delta_{6}\left(N J S_{i} * E S P_{i}\right) \\
& \left.\quad+\sum_{j} \beta_{1} Z_{j i}+\alpha E S P_{i}\right] \\
& P_{W L i}=\Phi\left[\beta_{0}+\beta_{1} \ln R W_{b i}+\delta_{1} I R W L l_{i}\right. \\
& \quad+\delta_{2} S P L L 6_{i}+\delta_{3} N J S_{i}+\delta_{4}\left(I R W L 1_{i} * E S P_{i}\right) \\
& \quad+\delta_{5}\left(S P L L 6_{i} * E S P_{i}\right)+\delta_{6}\left(N J S_{i} * E S P_{i}\right) \\
& \left.\quad+\sum_{i} \beta_{1 j} Z_{j i}+\alpha E S P_{i}\right]
\end{aligned}
$$

where $P_{R W L}=$ the probability of reducing reservation wage, and $P_{W L}=$ the probability of a wage loss, $I R W L 1$ = dummy variable indicating whether the IRW ratio is less than $1(=1)$ or not $(=0)$; SPLL6 = dummy variable indicating whether an individual was reemployed within 6 months $(=1)$ or not $(=0)$; and $N J S=$ dummy variable indicating whether an individual conducted no job-search activity $(=1)$ or $\operatorname{not}(=0)$.

\section{Duration of Unemployment}

A major purposes of ESP was to expedite displaced workers' full-time reemployment; measuring the "duration" of unemployment directly indicates the extent to which ESP was effective in achieving its goal. This paper defines unemployment duration (denoted as DUR) as "the number of months after random assignment before an individual becomes reemployed in his first full-time job." Analyzing this outcome with conventional methods would create a dynamic selection problem: a different fraction of program and control group members exits from the sampling frame in a given spell, thereby causing selection to occur in each of the spells. An even more serious problem arises when analyzing duration data due to the presence of sample members who still remain unemployed at the end of the follow-up period (censored observations). Simple OLS approach produces biased estimates by using only completed spells and discarding censored observations because censored observations have a duration length that is at least as large as uncensored values. To account for these problems, I use discrete-time logit survival model. This approach has important advantages compared to other conventional methods. First, the ESP data record unemployment or UI data in discrete units, most by the month and some by the week. By using the discrete method, I worried less about invoking inaccurate statistical approximation that would have been invoked had I used a continuous method for discrete data (Allison, 1982). Secondly, since the ESP eligibility period was 26 weeks, the hazard 
probability is expected to rise near the end of that period and therefore assessing the duration dependence becomes an important issue. Discrete-time logit models are well suited to that purpose because they allow flexible estimation of "baseline hazard" by simply including time dummies or other functional forms of time variables. Thirdly, by using discrete-time hazard models, one can minimize imposing excessive parametric assumptions that often turn out to be problematic, depending on the shape of the empirical hazard function (e.g., when empirical hazard is not monotonic) (Moffit, 1985). Finally, since one of the primary purposes of this chapter is to measure the marginal effect of various independent variables (including ESP), conventional logit specification provides a convenient way to interpret these effects (Singer \& Willet, 1993).

The following empirical model is specified.

$$
\begin{gathered}
\log \left(\frac{h_{i j}}{1-h_{i j}}\right)=\sum_{k=1}^{15} \alpha_{k} M O N T H_{k i j}+\delta E S P_{i} \\
+\beta_{1} \ln W_{p i}+\beta_{2} \ln \left(\frac{R W_{b}}{W_{p}}\right)_{i}+\sum \beta_{3 l} Z_{l i} \\
+\beta_{4} I R W L 1_{i}+\sum_{m} \beta_{5 m} J S E_{m i} \\
M O N T H_{\mathrm{kij}}=1, \text { when } k=j . \\
\text { MONTH }_{\mathrm{kij}}=0, \text { when } k \neq j .
\end{gathered}
$$

where $h_{i j}=$ hazard probability to reemployment for $i$-th individual at $j$-th time period, MONTH $=$ monthly time dummy indicators, $Z=$ all other independent variables.

Note that ESP was designed to expedite full-time employment only infor lower-paying job, not forin higher-paying jobs. In other words, in each month, an individual is "at risk" of either becoming reemployed to a higher-paying job or to a lower-paying job, butand ESP is likely to affect both risks differently. Given this, it is imperative to examine the dynamics of leaving unemployment in conjunction with the decision of relative wage levels. This can be doneachieved by viewing reemployment to a lower-paying job and reemployment to a higherpaying job as two separate events in order to specify a competing-risks model.7) Therefore I analyze competing risks model by estimating a multinomial logit specification, which is an extension of binomial logit. The following empirical models are specified.

$$
\begin{aligned}
& \log \left(\frac{h_{i j L}}{h_{i j 0}}\right)=\sum_{k=1}^{15} \alpha_{k L} M O N T H_{k i j} \\
& +\delta_{L} E S P_{i}+\beta_{1 L} \ln W_{p i}+\beta_{2 L} \ln \left(\frac{R W_{b}}{W_{p}}\right)_{i} \\
& +\sum_{i} \beta_{3 l L} Z_{l i}+\beta_{4 L} I R W 1_{i}+\sum_{m} \beta_{5 m L} J S E_{m i} \\
& \log \left(\frac{h_{i j H}}{h_{i j 0}}\right)=\sum_{k=1}^{15} \alpha_{k H} M O N T H_{k i j} \\
& \quad+\delta_{H} E S P_{i}+\beta_{1 H} \ln W_{p i}+\beta_{2 H} \ln \left(\frac{R W_{b}}{W_{p}}\right)_{i} \\
& \quad+\sum_{i} \beta_{3 l H} Z_{l i}+\beta_{4 H} I R W L 1_{i}+\sum_{m} \beta_{5 m H} J S E_{m i}
\end{aligned}
$$

where $h_{i j L}=$ probability of being employed in a lower-paying job, $h_{i j H}=$ probability of being employed in a higher-paying job, $h_{i j 0}=$ probability of not being employed.

\section{EMPIRICAL RESULTS}

\section{Findings}

Table 2 reports the results of the above empirical analyses and Table 3 summarizes these results in a schematic fashion. In Table 3 , the plus sign $(+)$ denotes a statistically significantly positive association between two variables, and the minus sign (-) denotes a statistically significantly negative asso-

7) The types of job in each event type differwill be different byfor different individuals. For example, for a person a job that paysing $\$ 10$ per an hour may be considered a higher-paying job for one person, but, for another it may be a lower-paying job for another person.

8) In estimating higher-paying job hazards, for example, lower-paying reemployment events are included in the estimation data and treated as censored at the time of reemployment. 
ciation. The question mark (?) denotes that no statistically significant relationship has been found between two variables.

As shown in both tables, ESP's impact turned out to be significant for most of the outcomes. The ESP program group members significantly lowered their reservation wages and, subsequently, experienced larger earnings loss than did control group members. However, ESP significantly affected job-search extensity but not job-search intensity, implying that the ESP only helped workers consider a broader range of job choices. The ESP program group members experienced a higher probability of leaving unemployment, but only in the lower-paying jobs. High-wage earners appeared to be more likely to lower their reservation wages during their period of unemployment. As a consequence, they became reemployed faster in lower-paying jobs but slower in higher-paying jobs than did the other displaced workers. Similarly, high initial reservation wage (IRW) workers were more likely to experience earnings loss at reemployment. But those who had an IRW higher than their previous wage showed a relatively high probability of being reemployed in a higher-paying job. Interestingly, however, the relative level of initial reservation wages is not statistically significantly associated with the level of search effort. Having an IRW ratio less than 1 is significantly positively associated with the probability of an earnings loss, as one can expect.9) However, it is significantly negatively associated with the probability of a reservation wage reduction, implying that individuals were reluctant to reduce their reservation wages further once they had initially set their reservation wages low. The impact of job-search intensity on the reemployment hazard probability was found to be positive, especially through the impact of being reemployed in a lower-paying job on the hazard

9) As will beis discussed, the initial reservation wage is one of the most important predictors for wage loss, which has important implication for policy makers. probability. In contrast, job- search extensity did not have any statistically significant effect on reemployment hazard probability. As the wellknown reservation wage property suggests, the unemployed persons continued to reduce their reservation wages as their unemployment spell progressed. Site variation between Saskatoon and Toronto is present for all outcomes examined. Saskatoon workers showed less job-search effort, were more likely to lower their reservation wages and experience earnings loss, and had a higher probability of being reemployed than did Toronto workers. However, the higher reemployment hazard probability of Saskatoon workers primarily came from reemployment in lower-paying jobs. Findings about the effect of $\mathrm{UI}$ benefits are mixed. Longer duration of UI entitlement is associated with a higher IRW ratio, higher job-search extensity, and higher wage replacement (WR) ratio. This implies that a longer UI benefit duration lowered the opportunity cost of being unemployed for displaced workers (its effect on their IRW ratio) and encouraged more active job search by subsidizing the direct cost of search (its effect on their job search extensity), and thereby led workers to become reemployed at high relative wages (its effect on WR ratio). On the other hand, UI insurable earnings are negatively associated with the IRW ratio and the WR ratio and positively associated with job-search extensity and the reemployment hazard probability. However, as noted, these findings may be because the Canadian UI system defines benefit level as a direct proportion of previous wages (i.e., 55\% of prior earnings; see Bloom et al. [1997], p. 2). The effect of human capital (both general and specific) was fairly consistent across all the outcomes examined. Highly educated workers (high level of general human capital) were more likely to set their relative initial reservation wages high, more likely to search harder, less likely to reduce reservation wages during their job search, and, consequently, became reemployed faster at 
Table 2. Results of Empirical Analyses

\begin{tabular}{|c|c|c|c|c|c|c|c|c|}
\hline \multirow[t]{2}{*}{ Independent Variables } & $\begin{array}{l}\text { IRW } \\
\text { Ratio }\end{array}$ & $\begin{array}{c}\text { Search } \\
\text { Intensity }\end{array}$ & $\begin{array}{c}\text { Search } \\
\text { Extensity }\end{array}$ & $\mathbf{P}_{\mathbf{R W L}}$ & $P_{w L}$ & $\begin{array}{c}\text { Total } \\
\text { Hazard }\end{array}$ & $\begin{array}{c}\text { L-paying } \\
\text { Hazard }\end{array}$ & $\begin{array}{c}\text { H-paying } \\
\text { Hazard }\end{array}$ \\
\hline & $(2)$ & (3) & $(4)$ & $(7)$ & $(8)$ & $(9)$ & $(10)-1$ & $(10)-2$ \\
\hline 1 months after random assignment & - & - & - & - & - & $\begin{array}{c}-3.100^{* * *} \\
(0.584)\end{array}$ & - & - \\
\hline 2 months after random assignment & - & - & - & - & - & $\begin{array}{c}-4.325^{* * *} \\
(0.587)\end{array}$ & $\begin{array}{c}-1.113^{* * *} \\
(0.099)\end{array}$ & $\begin{array}{c}-1.200^{* * *} \\
(0.141)\end{array}$ \\
\hline 3 months after random assignment & - & - & - & - & - & $\begin{array}{c}-4.367^{* * *} \\
(0.588)\end{array}$ & $\begin{array}{c}-1.123^{* * *} \\
(0.103)\end{array}$ & $\begin{array}{c}-1.313^{* * *} \\
(0.154)\end{array}$ \\
\hline 4 months after random assignment & - & - & - & - & - & $\begin{array}{c}-4.229 * * * \\
(0.588)\end{array}$ & $\begin{array}{c}-0.992 * * * \\
(0.102)\end{array}$ & $\begin{array}{c}-1.178^{* * *} \\
(0.152)\end{array}$ \\
\hline 5 months after random assignment & - & - & - & - & - & $\begin{array}{c}-4.384^{* * * *} \\
(0.588)\end{array}$ & $\begin{array}{c}-1.199 * * * \\
(0.114)\end{array}$ & $\begin{array}{c}-1.209 * * * \\
(0.159)\end{array}$ \\
\hline 6 months after random assignment & - & - & - & - & - & $\begin{array}{c}-4.135^{* * *} \\
(0.587)\end{array}$ & $\begin{array}{c}-0.852 * * * \\
(0.104)\end{array}$ & $\begin{array}{c}-1.218^{* * *} \\
(0.165)\end{array}$ \\
\hline 7 months after random assignment & - & - & - & - & - & $\begin{array}{c}-4.405 * * * \\
(0.589)\end{array}$ & $\begin{array}{c}-1.175^{* * *} \\
(0.121)\end{array}$ & $\begin{array}{c}-1.324 * * * \\
(0.180)\end{array}$ \\
\hline 8 months after random assignment & - & - & - & - & - & $\begin{array}{c}-4.377^{* * *} \\
(0.590)\end{array}$ & $\begin{array}{c}-1.257 * * * \\
(0.129)\end{array}$ & $\begin{array}{c}-1.084^{* * * *} \\
(0.170)\end{array}$ \\
\hline 9 months after random assignment & - & - & - & -- & - & $\begin{array}{c}-4.437^{* * * *} \\
(0.591)\end{array}$ & $\begin{array}{c}-1.278^{* * *} \\
(0.134)\end{array}$ & $\begin{array}{c}-1.210^{* * * *} \\
(0.185)\end{array}$ \\
\hline 10 months after random assignment & - & - & - & - & - & $\begin{array}{c}-4.348^{* * *} \\
(0.591)\end{array}$ & $\begin{array}{c}-1.097 * * * \\
(0.128)\end{array}$ & $\begin{array}{c}-1.334 * * * \\
(0.200)\end{array}$ \\
\hline 11 months after random assignment & - & - & - & - & - & $\begin{array}{c}-4.265^{* * *} \\
(0.591)\end{array}$ & $\begin{array}{c}-1.182 * * * \\
(0.137)\end{array}$ & $\begin{array}{c}-0.917^{* * * *} \\
(0.176)\end{array}$ \\
\hline 12 months after random assignment & - & - & - & - & - & $\begin{array}{c}-4.280 * * * \\
(0.592)\end{array}$ & $\begin{array}{c}-1.112 * * * \\
(0.137)\end{array}$ & $\begin{array}{c}-1.083^{* * *} \\
(0.195)\end{array}$ \\
\hline 13 months after random assignment & - & - & - & - & - & $\begin{array}{c}-4.221^{* * *} \\
(0.592)\end{array}$ & $\begin{array}{c}-0.940^{* * *} \\
(0.132)\end{array}$ & $\begin{array}{c}-1.308^{* * *} \\
(0.223)\end{array}$ \\
\hline 14 months after random assignment & - & - & - & - & - & $\begin{array}{c}-4.170^{* * *} \\
(0.592)\end{array}$ & $\begin{array}{c}-0.947^{* * *} \\
(0.137)\end{array}$ & $\begin{array}{c}-1.103^{* * *} \\
(0.211)\end{array}$ \\
\hline 15 months after random assignment & - & - & - & - & - & $\begin{array}{c}-4.408 * * * \\
(0.595)\end{array}$ & $\begin{array}{c}-1.138^{* * *} \\
(0.154)\end{array}$ & $\begin{array}{c}-1.447^{* * *} \\
(0.255)\end{array}$ \\
\hline $\log \left(W_{p}\right)$ & - & $\begin{array}{c}0.656 \\
(0.843)\end{array}$ & $\begin{array}{c}-2.110 \\
(1.753)\end{array}$ & $\begin{array}{c}0.948^{* * *} \\
(0.115)\end{array}$ & - & $\begin{array}{c}-0.038 \\
(0.096)\end{array}$ & $\begin{array}{c}0.556^{* * * *} \\
(0.111)\end{array}$ & $\begin{array}{c}-1.194^{* * *} \\
(0.165)\end{array}$ \\
\hline $\log \left(R W_{b}\right)$ & - & - & - & - & $\begin{array}{c}0.752^{* * *} \\
(0.124)\end{array}$ & - & - & - \\
\hline IRW Ratio [ $\left.\log \left(R W_{b} / W_{p}\right)\right]$ & - & - & - & - & - & $\begin{array}{c}0.152 \\
(0.117)\end{array}$ & $\begin{array}{c}0.020 \\
(0.129)\end{array}$ & $\begin{array}{c}0.645^{* * *} \\
(0.212)\end{array}$ \\
\hline$R W_{b} / W_{p}<1$ & - & - & - & $\begin{array}{c}-0.570^{* * *} \\
(0.085)\end{array}$ & $\begin{array}{c}0.652^{* * *} \\
(0.088)\end{array}$ & $\begin{array}{l}0.105^{*} \\
(0.057)\end{array}$ & $\begin{array}{c}0.345^{* * *} \\
(0.070)\end{array}$ & $\begin{array}{c}-0.218^{* *} \\
(0.096)\end{array}$ \\
\hline Job-search time $: 1 \sim 7$ hours & - & - & - & - & - & $\begin{array}{c}0.294^{* *} \\
(0.147)\end{array}$ & $\begin{array}{l}0.292^{*} \\
(0.174)\end{array}$ & $\begin{array}{c}0.167 \\
(0.265)\end{array}$ \\
\hline Job-search time : $8 \sim 15$ hours & - & - & - & - & - & $\begin{array}{c}0.399 * * * \\
(0.144)\end{array}$ & $\begin{array}{c}0.472 * * * \\
(0.169)\end{array}$ & $\begin{array}{c}0.107 \\
(0.262)\end{array}$ \\
\hline Job-search time : $16 \sim 25$ hours & - & - & - & - & - & $\begin{array}{c}0.512^{* * * *} \\
(0.144)\end{array}$ & $\begin{array}{c}0.529^{* * *} \\
(0.170)\end{array}$ & $\begin{array}{c}0.334 \\
(0.260)\end{array}$ \\
\hline Job-search time : 26 hours or more & - & - & - & - & - & $\begin{array}{c}0.565^{* * *} \\
(0.148)\end{array}$ & $\begin{array}{c}0.640^{* * *} \\
(0.174)\end{array}$ & $\begin{array}{c}0.260 \\
(0.268)\end{array}$ \\
\hline \# of firms contacted : $1 \sim 5$ firms & - & - & - & - & - & $\begin{array}{c}-0.023 \\
(0.097)\end{array}$ & $\begin{array}{c}-0.083 \\
(0.114)\end{array}$ & $\begin{array}{c}0.179 \\
(0.175)\end{array}$ \\
\hline
\end{tabular}




\begin{tabular}{|c|c|c|c|c|c|c|c|c|}
\hline \multirow[t]{2}{*}{ Independent Variables } & $\begin{array}{l}\text { IRW } \\
\text { Ratio }\end{array}$ & $\begin{array}{l}\text { Search } \\
\text { Intensity } \mathrm{F}\end{array}$ & $\begin{array}{c}\text { Search } \\
\text { Extensity }\end{array}$ & $P_{\text {RWL }}$ & $P_{W L}$ & $\begin{array}{l}\text { Total } \\
\text { Hazard }\end{array}$ & $\begin{array}{l}\text { L-paying } \\
\text { Hazard }\end{array}$ & $\begin{array}{l}\text { H-paying } \\
\text { Hazard }\end{array}$ \\
\hline & $(2)$ & (3) & (4) & (7) & (8) & $(9)$ & $(10)-1$ & $(10)-2$ \\
\hline \# of firms contacted : $6 \sim 15$ firms & - & - & - & - & - & $\begin{array}{c}0.061 \\
(0.091)\end{array}$ & $\begin{array}{c}0.046 \\
(0.105)\end{array}$ & $\begin{array}{c}0.151 \\
(0.167)\end{array}$ \\
\hline \# of firms contacted : $16 \sim 25$ firms & - & - & - & - & - & $\begin{array}{c}0.020 \\
(0.100)\end{array}$ & $\begin{array}{l}-0.003 \\
(0.116)\end{array}$ & $\begin{array}{c}0.101 \\
(0.181)\end{array}$ \\
\hline \# of firms contacted : $26 \sim 40$ firms & - & - & - & - & - & $\begin{array}{c}0.038 \\
(0.105)\end{array}$ & $\begin{array}{c}0.026 \\
(0.124)\end{array}$ & $\begin{array}{c}0.134 \\
(0.189)\end{array}$ \\
\hline \# of firms contacted : 41 firms or more & - & - & - & - & - & $\begin{array}{l}0.246^{* *} \\
(0.106)\end{array}$ & $\begin{array}{l}0.232^{*} \\
(0.123)\end{array}$ & $\begin{array}{c}0.275 \\
(0.190)\end{array}$ \\
\hline Monthly unemployment rate & - & - & - & - & - & - & - & - \\
\hline Monthly UI benefit amount & - & - & - & - & - & - & - & - \\
\hline Unemployment Spell $<=6$ months & - & - & - & $\begin{array}{c}-0.182^{* *} \\
(0.078)\end{array}$ & $\begin{array}{c}-0.182^{* *} \\
(0.085)\end{array}$ & - & - & - \\
\hline No job-search activity & - & - & - & $\begin{array}{c}-0.242 \\
(0.211)\end{array}$ & $\begin{array}{c}-0.524 * * * \\
(0.191)\end{array}$ & - & - & - \\
\hline Reservation wage ratio $\left[\log \left(R W_{b} / W_{p}\right)\right]$ & - & $\begin{array}{c}0.968 \\
(0.895)\end{array}$ & $\begin{array}{c}1.598 \\
(1.887)\end{array}$ & - & - & - & - & - \\
\hline ESP Program group & - & $\begin{array}{c}0.505 \\
(0.385)\end{array}$ & $\begin{array}{l}1.969^{* *} \\
(0.804)\end{array}$ & $\begin{array}{l}-0.109 \\
(0.117)\end{array}$ & $\begin{array}{l}-0.082 \\
(0.120)\end{array}$ & $\begin{array}{c}0.094 * * \\
(0.043)\end{array}$ & $\begin{array}{c}0.164^{* * *} \\
(0.051)\end{array}$ & $\begin{array}{l}-0.060 \\
(0.074)\end{array}$ \\
\hline Program group $* R W_{b} / W_{p}<1$ & - & - & - & $\begin{array}{c}0.074 \\
(0.111)\end{array}$ & $\begin{array}{c}0.020 \\
(0.116)\end{array}$ & - & - & - \\
\hline $\begin{array}{l}\text { Program group * Unemployment spell } \\
<6\end{array}$ & - & - & - & $\begin{array}{l}0.269^{* *} \\
(0.111)\end{array}$ & $\begin{array}{l}0.276^{* *} \\
(0.118)\end{array}$ & - & - & - \\
\hline Program group * No search activity & - & - & - & $\begin{array}{l}0.564^{*} \\
(0.314)\end{array}$ & $\begin{array}{c}0.909^{* * *} \\
(0.295)\end{array}$ & - & - & - \\
\hline Granby & $\begin{array}{l}-0.062^{* * *} \\
(0.021)\end{array}$ & $\begin{array}{l}-3.194^{* * *} \\
(1.109)\end{array}$ & $\begin{array}{l}-5.628 \\
(2.301)\end{array}$ & $\begin{array}{c}0.120 \\
(0.143)\end{array}$ & $\begin{array}{l}0.292^{*} \\
(0.161)\end{array}$ & $\begin{array}{c}0.409^{* * *} \\
(0.120)\end{array}$ & $\begin{array}{c}0.541^{* * *} \\
(0.141)\end{array}$ & $\begin{array}{c}0.105 \\
(0.213)\end{array}$ \\
\hline Oshawa & $\begin{array}{c}-0.041^{* * *} \\
(0.013)\end{array}$ & $\begin{array}{c}-0.186 \\
(0.706)\end{array}$ & $\begin{array}{c}1.729 \\
(1.478)\end{array}$ & $\begin{array}{l}-0.093 \\
(0.087)\end{array}$ & $\begin{array}{c}0.026 \\
(0.094)\end{array}$ & $\begin{array}{c}-0.026 \\
(0.079)\end{array}$ & $\begin{array}{c}-0.001 \\
(0.095)\end{array}$ & $\begin{array}{l}-0.019 \\
(0.134)\end{array}$ \\
\hline Saskatoon & $\begin{array}{c}-0.078^{* * *} \\
(0.013)\end{array}$ & $\begin{array}{c}-1.622^{* *} \\
(0.712)\end{array}$ & $\begin{array}{c}-3.194^{* *} \\
(1.496)\end{array}$ & $\begin{array}{l}0.180^{*} \\
(0.099)\end{array}$ & $\begin{array}{c}0.326^{* * * *} \\
(0.109)\end{array}$ & $\begin{array}{c}0.397 * * * \\
(0.079)\end{array}$ & $\begin{array}{c}0.546 * * * \\
(0.095)\end{array}$ & $\begin{array}{c}0.015 \\
(0.133)\end{array}$ \\
\hline Winnipeg & $\begin{array}{c}-0.075^{* * *} \\
(0.014)\end{array}$ & $\begin{array}{c}-1.976^{* * *} \\
(0.756)\end{array}$ & $\begin{array}{c}-1.263 \\
(1.586)\end{array}$ & $\begin{array}{l}0.184^{*} \\
(0.100)\end{array}$ & $\begin{array}{c}0.355^{* * *} \\
(0.110)\end{array}$ & $\begin{array}{c}0.231^{* * *} \\
(0.084)\end{array}$ & $\begin{array}{c}0.403^{* * *} \\
(0.100)\end{array}$ & $\begin{array}{l}-0.193 \\
(0.147)\end{array}$ \\
\hline Age & $\begin{array}{c}0.004 \\
(0.003)\end{array}$ & $\begin{array}{c}0.775 * * * \\
(0.137)\end{array}$ & $\begin{array}{c}1.097^{* * *} \\
(0.283)\end{array}$ & - & - & $\begin{array}{c}0.049 * * * \\
(0.017)\end{array}$ & $\begin{array}{c}0.068^{* *} \\
(0.021)\end{array}$ & $\begin{array}{c}0.026 \\
(0.029)\end{array}$ \\
\hline $\mathrm{Age}^{2}$ & $\begin{array}{c}0.000 \\
(0.000)\end{array}$ & $\begin{array}{c}-0.010^{* * *} \\
(0.002)\end{array}$ & $\begin{array}{c}-0.015^{* * *} \\
(0.003)\end{array}$ & - & - & $\begin{array}{c}-0.001^{* * *} \\
(0.000)\end{array}$ & $\begin{array}{c}-0.001^{* * *} \\
(0.000)\end{array}$ & $\begin{array}{c}-0.001^{* *} \\
(0.000)\end{array}$ \\
\hline Male & $\begin{array}{c}0.025^{* * *} \\
(0.009)\end{array}$ & $\begin{array}{c}3.173^{* * *} \\
(0.462)\end{array}$ & $\begin{array}{c}1.545 \\
(0.966)\end{array}$ & $\begin{array}{c}-0.152^{* *} \\
(0.070)\end{array}$ & $\begin{array}{c}-0.233^{* * *} \\
(0.075)\end{array}$ & $\begin{array}{c}0.346^{* * *} \\
(0.051)\end{array}$ & $\begin{array}{c}0.219^{* * *} \\
(0.061)\end{array}$ & $\begin{array}{c}0.535 * * * \\
(0.086)\end{array}$ \\
\hline Married & $\begin{array}{c}0.001 \\
(0.010)\end{array}$ & $\begin{array}{c}0.508 \\
(0.531)\end{array}$ & $\begin{array}{c}0.737 \\
(1.108)\end{array}$ & - & - & $\begin{array}{c}0.001 \\
(0.059)\end{array}$ & $\begin{array}{c}0.021 \\
(0.070)\end{array}$ & $\begin{array}{c}-0.014 \\
(0.101)\end{array}$ \\
\hline Own place of residence & $\begin{array}{c}0.012 \\
(0.010)\end{array}$ & $\begin{array}{l}-0.888^{*} \\
(0.528)\end{array}$ & $\begin{array}{l}-1.444 \\
(1.104)\end{array}$ & $\begin{array}{l}0.134^{*} \\
(0.072)\end{array}$ & $\begin{array}{l}0.147^{*} \\
(0.080)\end{array}$ & $\begin{array}{c}0.038 \\
(0.059)\end{array}$ & $\begin{array}{c}0.086 \\
(0.070)\end{array}$ & $\begin{array}{c}-0.064 \\
(0.105)\end{array}$ \\
\hline \# of household members: 2 adults & $\begin{array}{c}0.004 \\
(0.014)\end{array}$ & $\begin{array}{l}-1.051 \\
(0.736)\end{array}$ & $\begin{array}{l}-1.314 \\
(1.545)\end{array}$ & $\begin{array}{l}0.196^{* *} \\
(0.098)\end{array}$ & $\begin{array}{l}0.196^{*} \\
(0.105)\end{array}$ & $\begin{array}{l}-0.005 \\
(0.082)\end{array}$ & $\begin{array}{c}0.039 \\
(0.098)\end{array}$ & $\begin{array}{l}-0.166 \\
(0.143)\end{array}$ \\
\hline \# of household members: 3 or more & $\begin{array}{l}-0.002 \\
(0.015)\end{array}$ & $\begin{array}{c}0.309 \\
(0.803)\end{array}$ & $\begin{array}{l}-0.507 \\
(1.690)\end{array}$ & $\begin{array}{c}0.066 \\
(0.096)\end{array}$ & $\begin{array}{c}0.024 \\
(0.105)\end{array}$ & $\begin{array}{c}0.189^{* *} \\
(0.088)\end{array}$ & $\begin{array}{c}0.143 \\
(0.106)\end{array}$ & $\begin{array}{c}0.196 \\
(0.149)\end{array}$ \\
\hline
\end{tabular}




\begin{tabular}{|c|c|c|c|c|c|c|c|c|}
\hline \multirow[t]{2}{*}{ Independent Variables } & $\begin{array}{l}\text { IRW } \\
\text { Ratio }\end{array}$ & $\begin{array}{l}\text { Search } \\
\text { Intensity }\end{array}$ & $\begin{array}{c}\text { Search } \\
\text { Extensity }\end{array}$ & $P_{\text {RWL }}$ & $\mathbf{P}_{\mathrm{WL}}$ & $\begin{array}{c}\text { Total } \\
\text { Hazard }\end{array}$ & $\begin{array}{l}\text { L-paying } \\
\text { Hazard }\end{array}$ & $\begin{array}{l}\text { H-paying } \\
\text { Hazard }\end{array}$ \\
\hline & (2) & (3) & (4) & (7) & $(8)$ & (9) & $(10)-1$ & $(10)-2$ \\
\hline Union member in previous job & $\begin{array}{l}-0.053^{* * *} \\
(0.0110)\end{array}$ & $\begin{array}{l}-1.599^{* *} \\
(0.580)\end{array}$ & $\begin{array}{l}-3.748^{* * *} \\
(1.215)\end{array}$ & $\begin{array}{c}0.045 \\
(0.084)\end{array}$ & $\begin{array}{l}0.229^{* *} \\
(0.096)\end{array}$ & $\begin{array}{l}-0.119^{*} \\
(0.066)\end{array}$ & $\begin{array}{l}-0.076 \\
(0.075)\end{array}$ & $\begin{array}{l}-0.284^{* *} \\
(0.137)\end{array}$ \\
\hline Received severance & $\begin{array}{l}-0.003 \\
(0.012)\end{array}$ & $\begin{array}{c}0.458 \\
(0.609)\end{array}$ & $\begin{array}{c}1.272 \\
(1.269)\end{array}$ & $\begin{array}{l}0.140^{* *} \\
(0.057)\end{array}$ & $\begin{array}{c}0.061 \\
(0.063)\end{array}$ & $\begin{array}{l}-0.090 \\
(0.066)\end{array}$ & $\begin{array}{l}-0.011 \\
(0.079)\end{array}$ & $\begin{array}{l}-0.200^{*} \\
(0.114)\end{array}$ \\
\hline Full-time previous job & $\begin{array}{l}0.034^{* *} \\
(0.015)\end{array}$ & $\begin{array}{l}2.746 * * * \\
(0.855)\end{array}$ & $\begin{array}{c}2.372 \\
(1.778)\end{array}$ & $\begin{array}{c}0.215 \\
(0.153)\end{array}$ & $\begin{array}{c}0.085 \\
(0.150)\end{array}$ & $\begin{array}{l}0.419^{* * *} \\
(0.109)\end{array}$ & $\begin{array}{c}0.530^{* * *} \\
(0.140)\end{array}$ & $\begin{array}{l}0.291^{*} \\
(0.174)\end{array}$ \\
\hline Search for jobs before layoff & $\begin{array}{c}0.011 \\
(0.009)\end{array}$ & $\begin{array}{l}-0.245 \\
(0.451)\end{array}$ & $\begin{array}{l}3.335 * * * \\
(0.945)\end{array}$ & $\begin{array}{c}-0.156^{* *} \\
(0.064)\end{array}$ & $\begin{array}{c}-0.179^{* * *} \\
(0.067)\end{array}$ & $\begin{array}{c}0.177^{* * *} \\
(0.050)\end{array}$ & $\begin{array}{l}0.107^{* *} \\
(0.060)\end{array}$ & $\begin{array}{l}0.297^{* * *} \\
(0.085)\end{array}$ \\
\hline $\begin{array}{l}\text { Local unemployment rate } 1 \text { month } \\
\text { b/f RA }\end{array}$ & $\begin{array}{c}0.949 \\
(0.6940)\end{array}$ & $\begin{array}{c}29.959 \\
(36.129)\end{array}$ & $\begin{array}{c}45.256 \\
(76.084)\end{array}$ & $\begin{array}{l}-2.579 \\
(3.397)\end{array}$ & $\begin{array}{l}-1.906 \\
(3.721)\end{array}$ & $\begin{array}{c}2.580 \\
(3.982)\end{array}$ & $\begin{array}{c}2.782 \\
(4.660)\end{array}$ & $\begin{array}{l}-1.277 \\
(7.116)\end{array}$ \\
\hline Local unemployment rate at RA & $\begin{array}{l}-0.500 \\
(0.867)\end{array}$ & $\begin{array}{l}-77.775^{*} \\
(45.435)\end{array}$ & $\begin{array}{c}-160.764^{*} \\
(94.711)\end{array}$ & $\begin{array}{c}0.852 \\
(3.885)\end{array}$ & $\begin{array}{c}1.203 \\
(4.175)\end{array}$ & $\begin{array}{c}2.621 \\
(4.998)\end{array}$ & $\begin{array}{l}2.339 \\
(5.870)\end{array}$ & $\begin{array}{c}1.047 \\
(8.797)\end{array}$ \\
\hline UI entitled weeks : $39 \sim 42$ weeks & $\begin{array}{c}0.028^{* * *} \\
(0.010)\end{array}$ & $\begin{array}{c}0.285 \\
(0.505)\end{array}$ & $\begin{array}{c}0.819 \\
(1.057)\end{array}$ & $\begin{array}{c}0.036 \\
(0.067)\end{array}$ & $\begin{array}{l}-0.018 \\
(0.073)\end{array}$ & $\begin{array}{c}0.060 \\
(0.056)\end{array}$ & $\begin{array}{l}0.074^{* *} \\
(0.067)\end{array}$ & $\begin{array}{c}0.067 \\
(0.094)\end{array}$ \\
\hline UI entitled weeks : $43 \sim 50$ weeks & $\begin{array}{c}0.015 \\
(0.012)\end{array}$ & $\begin{array}{c}0.437 \\
(0.636)\end{array}$ & $\begin{array}{l}2.506^{*} \\
(1.331)\end{array}$ & $\begin{array}{l}0.176^{* * *} \\
(0.086)\end{array}$ & $\begin{array}{c}0.108 \\
(0.093)\end{array}$ & $\begin{array}{l}-0.004 \\
(0.071)\end{array}$ & $\begin{array}{l}0.058^{* * *} \\
(0.084)\end{array}$ & $\begin{array}{l}-0.092 \\
(0.124)\end{array}$ \\
\hline $\begin{array}{l}\text { UI insurable earnings : } \$ 400 \sim 599 \\
\text { per week }\end{array}$ & $\begin{array}{l}-0.108^{* * *} \\
(0.011)\end{array}$ & $\begin{array}{l}-0.423 \\
(0.669)\end{array}$ & $\begin{array}{c}1.773 \\
(1.394)\end{array}$ & $\begin{array}{l}-0.065 \\
(0.091)\end{array}$ & $\begin{array}{l}0.164^{*} \\
(0.093)\end{array}$ & $\begin{array}{l}0.229^{* * *} \\
(0.075)\end{array}$ & $\begin{array}{l}0.231 * * \\
(0.094)\end{array}$ & $\begin{array}{c}0.361^{* * *} \\
(0.119)\end{array}$ \\
\hline $\begin{array}{l}\text { UI insurable earnings : } \$ 600 \sim 799 \\
\text { per week }\end{array}$ & $\begin{array}{c}-0.182^{* * *} \\
(0.013)\end{array}$ & $\begin{array}{l}-0.180 \\
(0.856)\end{array}$ & $\begin{array}{l}3.324^{*} \\
(1.798)\end{array}$ & $\begin{array}{l}-0.206^{*} \\
(0.121)\end{array}$ & $\begin{array}{c}0.076 \\
(0.123)\end{array}$ & $\begin{array}{c}0.454^{* * *} \\
(0.096)\end{array}$ & $\begin{array}{c}0.321 \\
(0.117)\end{array}$ & $\begin{array}{c}0.788^{* * *} \\
(0.158)\end{array}$ \\
\hline UI insurable earnings : $\$ 800$ or more & $\begin{array}{c}-0.264^{* * *} \\
(0.016)\end{array}$ & $\begin{array}{c}1.574 \\
(1.104)\end{array}$ & $\begin{array}{l}5.996^{* *} \\
(2.321)\end{array}$ & $\begin{array}{c}-0.375^{* *} \\
(0.156)\end{array}$ & $\begin{array}{c}0.045 \\
(0.156)\end{array}$ & $\begin{array}{c}0.493^{* * *} \\
(0.124)\end{array}$ & $\begin{array}{c}0.284 \\
(0.148)\end{array}$ & $\begin{array}{c}0.921^{* * *} \\
(0.216)\end{array}$ \\
\hline Monthly housing pay: $\$ 600 \sim \$ 1199$ & $\begin{array}{l}-0.005 \\
(0.011)\end{array}$ & $\begin{array}{c}0.610 \\
(0.554)\end{array}$ & $\begin{array}{c}0.456 \\
(1.156)\end{array}$ & $\begin{array}{l}-0.010 \\
(0.074)\end{array}$ & $\begin{array}{c}-0.113 \\
(0.083)\end{array}$ & $\begin{array}{c}0.012 \\
(0.062)\end{array}$ & $\begin{array}{l}-0.035 \\
(0.074)\end{array}$ & $\begin{array}{c}0.106 \\
(0.104)\end{array}$ \\
\hline Monthly housing pay: $\$ 1200 \sim \$ 1799$ & $\begin{array}{l}-0.023^{*} \\
(0.014)\end{array}$ & $\begin{array}{c}0.878 \\
(0.728)\end{array}$ & $\begin{array}{c}0.852 \\
(1.523)\end{array}$ & $\begin{array}{r}-0.069 \\
(0.101)\end{array}$ & $\begin{array}{l}-0.084 \\
(0.111)\end{array}$ & $\begin{array}{l}0.125 \\
(0.081)\end{array}$ & $\begin{array}{c}0.096 \\
(0.094)\end{array}$ & $\begin{array}{c}0.129 \\
(0.147)\end{array}$ \\
\hline Monthly housing pay: $\$ 1800$ or more & $\begin{array}{l}-0.003 \\
(0.017)\end{array}$ & $\begin{array}{l}1.639^{*} \\
(0.897)\end{array}$ & $\begin{array}{l}3.126^{*} \\
(1.870)\end{array}$ & $\begin{array}{l}-0.192 \\
(0.122)\end{array}$ & $\begin{array}{l}-0.332^{* *} \\
(0.133)\end{array}$ & $\begin{array}{c}-0.063 \\
(0.100)\end{array}$ & $\begin{array}{c}-0.216^{* *} \\
(0.120)\end{array}$ & $\begin{array}{l}0.320^{*} \\
(0.173)\end{array}$ \\
\hline \# of dependent children : 1 child & $\begin{array}{c}0.000 \\
(0.012)\end{array}$ & $\begin{array}{c}0.363 \\
(0.612)\end{array}$ & $\begin{array}{c}1.748 \\
(1.279)\end{array}$ & & & $\begin{array}{l}-0.145^{* *} \\
(0.067)\end{array}$ & $\begin{array}{l}-0.124 \\
(0.079)\end{array}$ & $\begin{array}{l}-0.175 \\
(0.117)\end{array}$ \\
\hline \# of dependent children : $2 \sim 3$ children & $\begin{array}{c}0.012 \\
(0.012)\end{array}$ & $\begin{array}{l}-1.076 \\
(0.656)\end{array}$ & $\begin{array}{c}0.053 \\
(1.367)\end{array}$ & & & $\begin{array}{c}-0.179 * * \\
(0.073)\end{array}$ & $\begin{array}{c}-0.166 * * \\
(0.086)\end{array}$ & $\begin{array}{l}-0.222 * \\
(0.126)\end{array}$ \\
\hline $\begin{array}{l}\text { \# of dependent children : } 4 \text { children } \\
\text { or more }\end{array}$ & $\begin{array}{c}0.012 \\
(0.037)\end{array}$ & $\begin{array}{c}1.150 \\
(1.895)\end{array}$ & $\begin{array}{l}6.024 \\
(4.024)\end{array}$ & & & $\begin{array}{l}-0.326 \\
(0.209)\end{array}$ & $\begin{array}{l}-0.249 \\
(0.242)\end{array}$ & $\begin{array}{l}-0.496 \\
(0.384)\end{array}$ \\
\hline $\begin{array}{l}\text { Number contributing to income : } \\
2 \text { adults }\end{array}$ & $\begin{array}{l}-0.023^{* *} \\
(0.010)\end{array}$ & $\begin{array}{l}-0.385 \\
(0.544)\end{array}$ & $\begin{array}{l}-0.568 \\
(1.142)\end{array}$ & $\begin{array}{l}-0.040 \\
(0.073)\end{array}$ & $\begin{array}{l}-0.007 \\
(0.080)\end{array}$ & $\begin{array}{l}-0.053 \\
(0.061)\end{array}$ & $\begin{array}{c}-0.042 \\
(0.072)\end{array}$ & $\begin{array}{l}-0.017 \\
(0.108)\end{array}$ \\
\hline $\begin{array}{l}\text { Number contributing to income : } \\
3 \text { or more }\end{array}$ & $\begin{array}{l}-0.017 \\
(0.019)\end{array}$ & $\begin{array}{l}-1.726^{*} \\
(0.974)\end{array}$ & $\begin{array}{l}-3.346 \\
(2.037)\end{array}$ & $\begin{array}{c}0.009 \\
(0.127)\end{array}$ & $\begin{array}{c}0.080 \\
(0.138)\end{array}$ & $\begin{array}{l}-0.123 \\
(0.107)\end{array}$ & $\begin{array}{l}-0.075 \\
(0.130)\end{array}$ & $\begin{array}{l}-0.188 \\
(0.177)\end{array}$ \\
\hline Highest education : High school & $\begin{array}{c}0.010 \\
(0.010)\end{array}$ & $\begin{array}{c}0.696 \\
(0.549)\end{array}$ & $\begin{array}{l}2.067^{*} \\
(1.147)\end{array}$ & $\begin{array}{l}-0.115 \\
(0.079)\end{array}$ & $\begin{array}{l}-0.126 \\
(0.088)\end{array}$ & $\begin{array}{c}0.063 \\
(0.063)\end{array}$ & $\begin{array}{l}-0.018 \\
(0.073)\end{array}$ & $\begin{array}{l}0.252^{* *} \\
(0.116)\end{array}$ \\
\hline Highest education : College & $\begin{array}{l}0.050^{* * * *} \\
(0.013)\end{array}$ & $\begin{array}{c}0.839 \\
(0.683)\end{array}$ & $\begin{array}{l}2.005 \\
(1.431)\end{array}$ & $\begin{array}{c}-0.193^{* *} \\
(0.097)\end{array}$ & $\begin{array}{l}-0.298^{* * *} \\
(0.104)\end{array}$ & $\begin{array}{c}0.121 \\
(0.077)\end{array}$ & $\begin{array}{c}-0.051 \\
(0.091)\end{array}$ & $\begin{array}{l}0.488^{* * *} \\
(0.135)\end{array}$ \\
\hline Highest education : University & $\begin{array}{c}0.087^{* * *} \\
(0.014)\end{array}$ & $\begin{array}{c}0.878 \\
(0.757)\end{array}$ & $\begin{array}{c}0.536 \\
(1.585)\end{array}$ & $\begin{array}{l}-0.284^{* * *} \\
(0.103)\end{array}$ & $\begin{array}{l}-0.362^{* * *} \\
(0.112)\end{array}$ & $\begin{array}{c}0.183^{* *} \\
(0.084)\end{array}$ & $\begin{array}{l}-0.074 \\
(0.101)\end{array}$ & $\begin{array}{c}0.669^{* * * *} \\
(0.143)\end{array}$ \\
\hline Previous job tenure & $\begin{array}{c}-0.008^{* * *} \\
(0.002)\end{array}$ & $\begin{array}{l}-0.138 \\
(0.088)\end{array}$ & $\begin{array}{l}-0.117 \\
(0.189)\end{array}$ & $\begin{array}{c}0.005 \\
(0.015)\end{array}$ & $\begin{array}{c}0.029^{* *} \\
(0.017)\end{array}$ & $\begin{array}{c}-0.062^{* * *} \\
(0.011)\end{array}$ & $\begin{array}{c}-0.042^{* * *} \\
(0.013)\end{array}$ & $\begin{array}{c}-0.095^{* * *} \\
(0.021)\end{array}$ \\
\hline
\end{tabular}




\begin{tabular}{|c|c|c|c|c|c|c|c|c|}
\hline Independent Variables & $\begin{array}{l}\text { IRW } \\
\text { Ratio }\end{array}$ & $\begin{array}{c}\text { Search } \\
\text { Intensity }\end{array}$ & $\begin{array}{c}\text { Search } \\
\text { Extensity }\end{array}$ & $P_{\text {RWL }}$ & $P_{W L}$ & $\begin{array}{c}\text { Total } \\
\text { Hazard }\end{array}$ & $\begin{array}{l}\text { L-paying } \\
\text { Hazard }\end{array}$ & $\begin{array}{c}\text { H-paying } \\
\text { Hazard }\end{array}$ \\
\hline & (2) & (3) & (4) & $(7)$ & $(8)$ & (9) & $(10)-1$ & $(10)-2$ \\
\hline Tenure $^{2}$ & $\begin{array}{l}0.000^{* *} \\
(0.000)\end{array}$ & $\begin{array}{l}-0.003 \\
(0.003)\end{array}$ & $\begin{array}{l}-0.005 \\
(0.006)\end{array}$ & $\begin{array}{c}0.000 \\
(0.001)\end{array}$ & $\begin{array}{c}0.000 \\
(0.001)\end{array}$ & $\begin{array}{c}0.001 \\
(0.000)\end{array}$ & $\begin{array}{c}0.000 \\
(0.000)\end{array}$ & $\begin{array}{l}0.001 \\
(0.001)\end{array}$ \\
\hline Industry tenure: $3 \sim 9$ years & $\begin{array}{l}-0.005 \\
(0.012)\end{array}$ & $\begin{array}{l}-0.166 \\
(0.648)\end{array}$ & $\begin{array}{l}-2.562^{*} \\
(1.350)\end{array}$ & $\begin{array}{c}0.001 \\
(0.084)\end{array}$ & $\begin{array}{l}-0.009 \\
(0.088)\end{array}$ & $\begin{array}{c}0.081 \\
(0.069)\end{array}$ & $\begin{array}{c}0.079 \\
(0.086)\end{array}$ & $\begin{array}{c}0.066 \\
(0.108)\end{array}$ \\
\hline Industry tenure: over 10 years & $\begin{array}{c}0.012 \\
(0.015)\end{array}$ & $\begin{array}{l}-1.234 \\
(0.783)\end{array}$ & $\begin{array}{c}-4.223 * * * \\
(1.625)\end{array}$ & $\begin{array}{l}-0.020 \\
(0.100)\end{array}$ & $\begin{array}{c}0.008 \\
(0.104)\end{array}$ & $\begin{array}{c}0.216^{* * *} \\
(0.083)\end{array}$ & $\begin{array}{c}0.157 \\
(0.102)\end{array}$ & $\begin{array}{l}0.228^{*} \\
(0.132)\end{array}$ \\
\hline Take school training after layoff & - & $\begin{array}{c}0.119 \\
(0.506)\end{array}$ & $\begin{array}{c}1.704 \\
(1.060)\end{array}$ & $\begin{array}{l}-0.109 \\
(0.072)\end{array}$ & $\begin{array}{c}-0.074 \\
(0.077)\end{array}$ & $\begin{array}{c}-0.307^{* * *} \\
(0.057)\end{array}$ & $\begin{array}{c}-0.309 * * * \\
(0.068)\end{array}$ & $\begin{array}{c}-0.239 * * \\
(0.096)\end{array}$ \\
\hline Take job skill traing after layoff & - & $\begin{array}{l}1.017^{* *} \\
(0.482)\end{array}$ & $\begin{array}{l}2.805^{* * *} \\
(1.012)\end{array}$ & $\begin{array}{c}0.009 \\
(0.066)\end{array}$ & $\begin{array}{l}-0.058 \\
(0.071)\end{array}$ & $\begin{array}{c}0.012 \\
(0.053)\end{array}$ & $\begin{array}{c}0.004 \\
(0.062)\end{array}$ & $\begin{array}{c}0.000 \\
(0.092)\end{array}$ \\
\hline $\begin{array}{l}\text { Receive job search assistance } \\
\text { after layoff }\end{array}$ & - & $\begin{array}{c}2.753^{* * *} \\
(0.428)\end{array}$ & $\begin{array}{l}5.464^{* * *} \\
(0.895)\end{array}$ & $\begin{array}{l}-0.004 \\
(0.059)\end{array}$ & $\begin{array}{c}0.027 \\
(0.063)\end{array}$ & $\begin{array}{l}-0.085^{*} \\
(0.048)\end{array}$ & $\begin{array}{l}-0.087 \\
(0.057)\end{array}$ & $\begin{array}{l}-0.080 \\
(0.084)\end{array}$ \\
\hline Primary industry & $\begin{array}{c}0.032 \\
(0.040)\end{array}$ & $\begin{array}{l}-2.002 \\
(2.136)\end{array}$ & $\begin{array}{c}0.889 \\
(4.382)\end{array}$ & $\begin{array}{c}-0.454^{*} \\
(0.274)\end{array}$ & $\begin{array}{c}-0.570^{* *} \\
(0.258)\end{array}$ & $\begin{array}{l}0.397^{*} \\
(0.227)\end{array}$ & $\begin{array}{c}0.149 \\
(0.287)\end{array}$ & $\begin{array}{l}0.820^{* *} \\
(0.342)\end{array}$ \\
\hline Manufacturing industry & $\begin{array}{l}-0.009 \\
(0.015)\end{array}$ & $\begin{array}{l}1.447^{*} \\
(0.791)\end{array}$ & $\begin{array}{c}0.569 \\
(1.658)\end{array}$ & $\begin{array}{l}-0.068 \\
(0.109)\end{array}$ & $\begin{array}{l}-0.145 \\
(0.118)\end{array}$ & $\begin{array}{c}0.050 \\
(0.088)\end{array}$ & $\begin{array}{c}0.030 \\
(0.102)\end{array}$ & $\begin{array}{c}0.171 \\
(0.165)\end{array}$ \\
\hline Construction industry & $\begin{array}{c}-0.019 \\
(0.027)\end{array}$ & $\begin{array}{l}-0.525 \\
(1.429)\end{array}$ & $\begin{array}{l}-1.512 \\
(2.972)\end{array}$ & $\begin{array}{l}-0.410^{* *} \\
(0.177)\end{array}$ & $\begin{array}{c}-0.504^{* *} \\
(0.197)\end{array}$ & $\begin{array}{l}0.355^{* *} \\
(0.150)\end{array}$ & $\begin{array}{c}0.065 \\
(0.186)\end{array}$ & $\begin{array}{c}0.893^{* * *} \\
(0.240)\end{array}$ \\
\hline $\begin{array}{l}\text { Transportation, communications, } \\
\text { utilities }\end{array}$ & $\begin{array}{l}-0.051^{* * *} \\
(0.018)\end{array}$ & $\begin{array}{c}1.263 \\
(0.930)\end{array}$ & $\begin{array}{c}1.916 \\
(1.963)\end{array}$ & $\begin{array}{l}-0.231^{*} \\
(0.129)\end{array}$ & $\begin{array}{c}-0.305^{* *} \\
(0.141)\end{array}$ & $\begin{array}{c}0.014 \\
(0.106)\end{array}$ & $\begin{array}{l}-0.084 \\
(0.122)\end{array}$ & $\begin{array}{l}0.358^{*} \\
(0.196)\end{array}$ \\
\hline Trade industry & $\begin{array}{c}-0.006 \\
(0.014)\end{array}$ & $\begin{array}{c}1.127 \\
(0.755)\end{array}$ & $\begin{array}{c}0.851 \\
(1.576)\end{array}$ & $\begin{array}{l}-0.135 \\
(0.103)\end{array}$ & $\begin{array}{l}-0.122 \\
(0.111)\end{array}$ & $\begin{array}{c}0.028 \\
(0.084)\end{array}$ & $\begin{array}{c}0.038 \\
(0.098)\end{array}$ & $\begin{array}{c}0.092 \\
(0.152)\end{array}$ \\
\hline Service industry & $\begin{array}{l}-0.012 \\
(0.013)\end{array}$ & $\begin{array}{l}-0.089 \\
(0.703)\end{array}$ & $\begin{array}{l}-2.123 \\
(1.471)\end{array}$ & $\begin{array}{l}-0.168^{*} \\
(0.097)\end{array}$ & $\begin{array}{c}-0.207^{* *} \\
(0.104)\end{array}$ & $\begin{array}{l}-0.058 \\
(0.079)\end{array}$ & $\begin{array}{l}-0.106 \\
(0.092)\end{array}$ & $\begin{array}{c}0.110 \\
(0.143)\end{array}$ \\
\hline Public administration industry & $\begin{array}{c}-0.072 * * * \\
(0.020)\end{array}$ & $\begin{array}{c}0.104 \\
(1.041)\end{array}$ & $\begin{array}{l}-0.273 \\
(2.209)\end{array}$ & $\begin{array}{l}-0.009 \\
(0.159)\end{array}$ & $\begin{array}{l}-0.041 \\
(0.173)\end{array}$ & $\begin{array}{c}-0.253^{* *} \\
(0.122)\end{array}$ & $\begin{array}{l}-0.234^{*} \\
(0.138)\end{array}$ & $\begin{array}{c}-0.284 \\
(0.245)\end{array}$ \\
\hline Occupation: White collar/service & $\begin{array}{c}0.027^{* *} \\
(0.010)\end{array}$ & $\begin{array}{l}0.967^{*} \\
(0.550)\end{array}$ & $\begin{array}{c}2.396^{* *} \\
(1.154)\end{array}$ & $\begin{array}{c}0.051 \\
(0.074)\end{array}$ & $\begin{array}{l}-0.152^{*} \\
(0.083)\end{array}$ & $\begin{array}{c}0.051 \\
(0.061)\end{array}$ & $\begin{array}{c}-0.052 \\
(0.072)\end{array}$ & $\begin{array}{l}0.271^{* *} \\
(0.106)\end{array}$ \\
\hline Experience some financial hardship & - & $\begin{array}{l}1.737^{* *} \\
(0.866)\end{array}$ & $\begin{array}{c}5.242^{* * *} \\
(1.818)\end{array}$ & $\begin{array}{c}0.049 \\
(0.114)\end{array}$ & $\begin{array}{c}0.129 \\
(0.123)\end{array}$ & $\begin{array}{c}-0.295 * * * \\
(0.097)\end{array}$ & $\begin{array}{c}-0.254^{* *} \\
(0.116)\end{array}$ & $\begin{array}{c}-0.405^{* *} \\
(0.160)\end{array}$ \\
\hline Experience severe financial hardship & - & $\begin{array}{c}2.557^{* * *} \\
(0.828)\end{array}$ & $\begin{array}{c}7.203 * * * \\
(1.740)\end{array}$ & $\begin{array}{l}0.208^{*} \\
(0.108)\end{array}$ & $\begin{array}{c}0.241^{* *} \\
(0.116)\end{array}$ & $\begin{array}{c}-0.462^{* * *} \\
(0.093)\end{array}$ & $\begin{array}{c}-0.346^{* * *} \\
(0.111)\end{array}$ & $\begin{array}{c}-0.707^{* * *} \\
(0.153)\end{array}$ \\
\hline Stay in the same industry & - & - & - & $\begin{array}{c}-0.218^{* * *} \\
(0.056)\end{array}$ & $\begin{array}{c}-0.119^{* *} \\
(0.060)\end{array}$ & - & - & - \\
\hline Stay in the same occupation & - & - & - & $\begin{array}{c}-0.092^{*} \\
(0.055)\end{array}$ & $\begin{array}{c}-0.082 \\
(0.059)\end{array}$ & - & - & - \\
\hline Sigma & - & $\begin{array}{c}11.743^{* * *} \\
(0.141)\end{array}$ & $\begin{array}{c}24.839^{* * *} \\
(0.305)\end{array}$ & - & - & - & - & - \\
\hline Constant & $\begin{array}{c}-0.108 \\
(0.086) \\
\end{array}$ & $\begin{array}{c}-2.223 \\
(4.982) \\
\end{array}$ & $\begin{array}{c}0.463 \\
(10.409) \\
\end{array}$ & $\begin{array}{c}-1.841 \\
(0.504) \\
\end{array}$ & $\begin{array}{l}-1.675 \\
(0.536) \\
\end{array}$ & - & $\begin{array}{c}-5.786^{* * *} \\
(0.701) \\
\end{array}$ & $\begin{array}{c}-0.508 \\
(1.001) \\
\end{array}$ \\
\hline R-square & 0.684 & & & & & & & \\
\hline Log-likelihood & & -14234.60 & -16527.65 & -3908 & -3682 & -8446 & & \\
\hline $\begin{array}{l}\text { Mean of Dependent Variable } \\
\text { Sample Size }\end{array}$ & $\begin{array}{c}-0.126 \\
4164\end{array}$ & $\begin{array}{l}18.1246 \\
3843\end{array}$ & $\begin{array}{c}20.771 \\
4068\end{array}$ & & & & & \\
\hline
\end{tabular}

a. Standard errors are given in parenthesis. Statistical significance was calculated using a two-tailed test. Statistical significance levels are indicated as: $* * *=0.01 ; * *=0.05 ;$ and ${ }^{*}=0.1$ 
Table 3. Schematic Summary of Empirical Findings

\begin{tabular}{|c|c|c|c|c|c|c|c|c|}
\hline & \multirow{2}{*}{$\begin{array}{c}\text { Initial } \\
\text { reservation } \\
\text { wage } R W_{b} / W_{p}\end{array}$} & \multicolumn{2}{|c|}{ Job search effort } & \multicolumn{2}{|c|}{ Reemployment wage } & \multicolumn{3}{|c|}{ Reemployment hazard probability } \\
\hline & & $\mathrm{T}_{\mathrm{JS}}$ & $\mathrm{N}_{\mathrm{JS}}$ & $\operatorname{Pr}\left(\mathrm{W}_{\mathrm{r}} / \mathrm{RW}_{\mathrm{b}}<1\right)$ & $\operatorname{Pr}\left(W_{p} / W_{p}<1\right)$ & $\begin{array}{c}\text { Total } \\
\text { hazard }\end{array}$ & $\begin{array}{l}\text { Lower- } \\
\text { paying }\end{array}$ & $\begin{array}{l}\text { Higher- } \\
\text { paying }\end{array}$ \\
\hline$W_{p}$ & . & $?(+)$ & $?(-)$ & + & & $?$ & + & - \\
\hline $\mathrm{RW}_{\mathrm{b}}$ & $\cdot$ & $\cdot$ & $\cdot$ & & + & & & \\
\hline$R W_{b} / W_{p}$ & $\cdot$ & $?(+)$ & $?(+)$ & & & $?$ & $?$ & + \\
\hline $\mathrm{RW}_{\mathrm{b}} / \mathrm{W}_{\mathrm{p}}<1$ & & & & - & + & & & \\
\hline Job search intensity $\left(\mathrm{T}_{\text {IS }}\right)$ & $\cdot$ & $\cdot$ & $\cdot$ & $?$ & $?$ & + & + & $?$ \\
\hline Job search extensity $\left(\mathrm{N}_{\mathrm{JS}}\right)$ & - & - & . & ? & $?$ & $?$ & $?$ & ? \\
\hline Unemployment Duration & $\cdot$ & $\cdot$ & $\cdot$ & & & & & \\
\hline ESP Supplement & . & $?$ & + & + & + & + & + & $?$ \\
\hline HRCC Site & · & & & & & & & \\
\hline Saskatoon & - & - & - & + & + & + & + & $?$ \\
\hline Toronto & + & + & + & - & - & - & - & $?$ \\
\hline \multicolumn{9}{|l|}{ UI Benefit Level } \\
\hline UI entitled weeks & + & ? & + & + & ? & ? & $?$ & $?$ \\
\hline UI insurable earnings & - & $?$ & + & - & + & + & + & + \\
\hline General human capital & + & $?(+)$ & + & - & - & + & $?$ & + \\
\hline Specific human capital & - & $?(-)$ & $?(-)$ & $?$ & + & - & - & - \\
\hline Wage premiums & - & - & - & $?$ & + & - & $?(-)$ & - \\
\hline White-collar occupation & + & 1 & + & $?$ & - & $?$ & $?$ & + \\
\hline $\begin{array}{l}\text { Stay in same industry or } \\
\text { occupation }\end{array}$ & $\cdot$ & $\cdot$ & - & - & - & & & \\
\hline Financial hardship & $\cdot$ & + & + & + & + & - & - & - \\
\hline
\end{tabular}

higher wages than did less educated workers. Similar effects were observed for white-collar workers. In contrast, long-tenured workers (with a high level of specific human capital) were more likely to set their relative initial reservation wages low, less likely to search, more willing to reduce their reservation wages, and, consequently, remained unemployed longer and became reemployed at lower wages than did short-tenured workers. Staying in the same industry or occupation is associated with lower probabilities of both reservation wage reduction and wage loss, implying that such workers retain industry- or occupation-specific skills in their next job. Interesting findings were obtained regarding the effect of financial hardship. Overall, individuals who experienced financial hardship pressed harder to leave unemployment early (i.e.. had a lower IRW ratio, more job-search effort, and a lower RWR ratio). However, their effort did not lead to favorable reemployment consequences, possibly because of their psychological depression and an inefficient search due to limited financial resources.

\section{Reasons for the ESP's Small Impacts}

Based on the empirical findings discussed above, in this section, I assess a series of hypotheses on why ESP had only a small impact as presented below. I bring together the findings summarized above to build an argument for each hypothesis.

- Hypothesis 1: A number of ESP participants might expect little or no increase in their lifetime earnings from ESP.

As shown in Table 3, results for all outcomes show a very clear and consistent pattern: workers with high education credentials, white-collar 
workers, and workers in knowledge-based industries were found to set relatively high initial reservation wages, to put forth grcater job search effort, and to be reemployed sooner at higher wages than others. These findings suggest that such workers may simply not have been interested in the ESP offer because they expected no earnings loss and thus no gain in lifetime wealth from receipt of the supplement.

In fact, for this reason, some participants may not have been interested in the ESP offer even if they "had" expected some earnings loss. Considering the generosity of ESP, ESP could have ensured an income (i.e., wage plus the supplement) close to the level of one's previous wage even though he or she accepted a lower-paying job. However, despite this fact, individuals may have been reluctant to lower their reservation wage and accept a lower-paying job because they may not have wanted to degrade their social status by accepting the lower-paying job.

- Hypothesis 2: ESP participants were not induced by the program to increase their job-search effort.

As indicated in Table 3, ESP had modest positive impacts on the wage-loss probability and the reemployment hazard probability (both of which are final outcomes). Upon close examination, it can be seen that these impacts were produced more through impacts on reservation wages than through impacts on job-search effort (both of which are intervening outcomes). In contrast to the finding that ESP induced participants to lower their reservation wages, ESP appears to have had no significant effect on job-search intensity (but some effect on job-search extensity). The evidence suggests that job-search effort was not a major link through which the impact of ESP was channeled. This finding is contradictory to the expectations derived from previous theoretical research (e.g.,
Davidson \& Woodbury, 1994). Given that participants responded to ESP mainly by lowering their reservation wages without increasing search intensity, the effectiveness of the program was probably limited.

- Hypothesis 3: ESP might have induced little net program impact because a reduction of the reservation wage was weakly or not linked to generating an impact on reemployment.

In principle, in order for ESP to have an impact, individuals must reduce their reservation wage because of ESP, at least below the level of their previous wage. However, it was found that a large number of individuals had already reduced their reservation wage before they received the ESP supplement offer, plus they were not willing to reduce their reservation wage further, thus leaving little margin to "induce" a program effect and creating a problem of deadweight loss. Notably, workers who enjoyed wage premiums in their previous jobs (whether job-specific, industryspecific, or union-specific) were found to have an especially low relative initial reservation wage. They were also found to have weaker job-search efforts, to receive relatively lower reemployment wages, and to stay unemployed longer. These findings suggest that wage-premium workers undergo harsh reemployment experiences (as was found), which may be due, in part, to a demoralized attitude and corresponding weaker job-search efforts when entering the reemployment labor market.

On the other hand, it is also possible that, even if participants lower their reservation wages further, the reduction in the rescrvation wages may have not led to reemployment, depending on the responsiveness of the demand side of the labor market. As shown in Table 4, the only group group (the group with an IRW ratio less than 0.8 : low IRW ratio group) that generated a statistically significant ESP impact on reemployment rate did not have any 
Table 4. Estimated RWR Ratio, WR Ratio, and Reemployment Rate by Distribution of IRW Ratio ${ }^{\mathrm{a}}$

\begin{tabular}{|c|c|c|c|c|c|c|c|c|c|}
\hline & \multicolumn{3}{|c|}{$\operatorname{RWR}_{\text {ratio }}{ }^{\circ}\left(\mathrm{W}_{\mathrm{r}} / \mathrm{RW} \mathrm{W}_{\mathrm{b}}\right)$} & \multicolumn{3}{|c|}{ WR ratio ${ }^{\mathrm{D}}\left(\mathrm{W}_{\mathrm{r}} / \mathrm{W}_{\mathrm{p}}\right)$} & \multicolumn{3}{|c|}{$\begin{array}{l}\text { Full-time employment rate within } \\
6 \text { months }\end{array}$} \\
\hline & $\begin{array}{l}\text { Program } \\
\text { group }\end{array}$ & $\begin{array}{l}\text { Control } \\
\text { group }\end{array}$ & Diff. & $\begin{array}{l}\text { Program } \\
\text { group }\end{array}$ & $\begin{array}{l}\text { Control } \\
\text { group }\end{array}$ & Diff. & $\begin{array}{l}\text { Program } \\
\text { group }\end{array}$ & $\begin{array}{l}\text { Control } \\
\text { group }\end{array}$ & Diff. \\
\hline $\mathrm{RW}_{\mathrm{b}} / \mathrm{W}_{\mathrm{p}}<0.8$ & 0.96 & 0.98 & -0.03 & 0.62 & 0.64 & -0.02 & $43.5 \%$ & $34.3 \%$ & $9.2 \% * * *$ \\
\hline $0.8<=\mathrm{RW}_{\mathrm{b}} / \mathrm{W}_{\mathrm{p}}<1$ & 0.89 & 0.93 & $-0.05^{* *}$ & 0.80 & 0.84 & $-0.04^{* *}$ & $44.8 \%$ & $41.3 \%$ & $3.5 \%$ \\
\hline $1<=\mathrm{RW}_{\mathrm{b}} / \mathrm{W}_{\mathrm{p}}$ & 0.86 & 0.86 & 0.00 & 0.94 & 0.94 & 0.00 & $40.7 \%$ & $36.9 \%$ & $3.8 \%$ \\
\hline
\end{tabular}

${ }^{a}$ Standard errors are given in parenthesis. Statistical significance was calculated using a two-tailed test. Statistical significance levels are indicated as: ${ }^{* * *}=0.01{ }^{* *}=0.05$; and $*=0.1$.

${ }^{b}$ Program and control group means of RWR ratio and WR ratio are adjusted by Heckman's 2-stage regression.

statistically significant ESP impact on RWR or WR ratio. In contrast, the group (the group with an IRW ratio between 0.8 and 1: middle IRW ratio group) that had a statistically significant impact on both RWR and WR ratios did not have statistically significant impact on reemployment rate.

This phenomenon may be a result of the different sensitivity of the market's response to the behavioral changes within the two groups. The low- and middle-IRW ratio groups have different worker characteristics, and the market may respond differently to the behavioral change of those workers with different characteristics. For example, it is possible that workers in the low IRW ratio group could have found a number of available job offers by reducing their reservation wage, whereas workers in the middle IRW ratio group could not, even if they had considerably reduced their reservation wage.

- Hypothesis 4: Many individuals might not be willing to lower their reservation wages, even to receive a temporary earnings supplement.

The magnitude of ESP impact in part depends upon how many were willing to lower their reservation wages further. Table 3 reveals that those who set their reservation wage initially lower than their previous wage were reluctant to reduce their reservation wage further during job search. Those less willing to further their reservation wage were

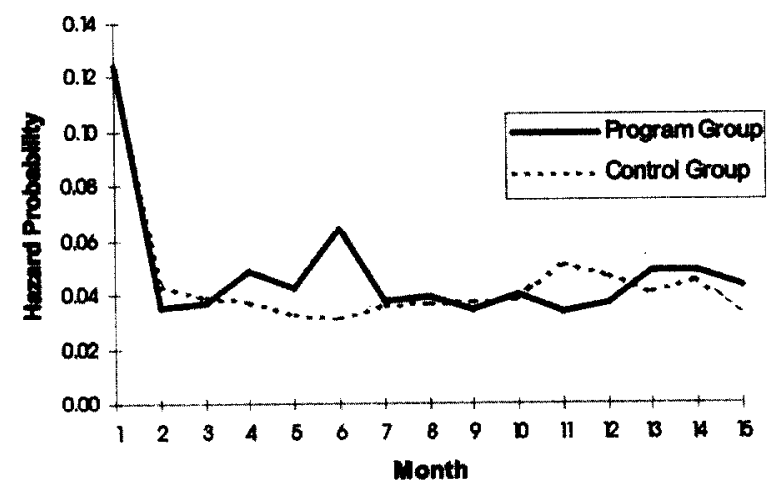

Figure 2. Discrete-time-logit estimated monthly hazard plot for program and control groups.

found to be highly educated workers, those with a high potential UI benefit level (or another source of income), and those who stayed in the same industry or occupation.

- Hypothesis 5: Even though ESP may have somewhat affected the timing of reemployment, it did not appreciably affect the overall level of employment.

It was found that ESP induced its participants to change their optimal timing of leaving unemployment, but it had a small impact on the duration of unemployment in aggregate. As shown in Figure 2, the program group's hazard profile begins to exceed the control group's profile beginning at the fourmonth point and reaching a high spike at the six-month point, when the program group's hazard 
probability $(6.4 \%)$ is twice that of the control group's (3.2\%).

This phenomenon was generated by two elements: (1) a concentration of program group exits from unemployment at the end of the eligibility period, and (2) a marked drop in exit rates thereafter, which were believed to be caused by time-limit features of ESP.

- Hypothesis 6: The impact was large for some sample members, but this group was only a small fraction of the whole sample.

It was found that Saskatoon, a small subset of the whole sample, had by far the largest impact among all the sites. As Table 3 illustrates, workers in Saskatoon (1) set their initial reservation wage lower, (2) exerted less job-search effort, (3) experienced more wage loss, (4) were more willing to lower their reservation wage during the job-search unemployment period, and (5) became reemployed faster in a lower-paying full-time job than did workers in Toronto, which had the smallest impact. These differences between the two sites stem from differences in the characteristics of their displaced workers and differences in their labor market conditions.

\section{DISCUSSION AND CONCLUSION}

This study has some important implications for policy makers. First and foremost, a policy instrument in which the mediator variable is designed to be the reservations wages of displaced workers, rather than their job-search activity, will probably not achieve its desired policy goals. If an earnings subsidy program is to have significant impact, participants should reduce their reservation wages at least to a level below their previous wages (regardless of whether they were initially lower or higher) in order to become reemployed faster than if they did not have ESP. However, as this paper found, it is highly uncertain that such a policy intervention would induce such a behavioral response; thus, it may be of benefit to consider a demand-side wage subsidy program, which gives a subsidy to employers.

It may also be beneficial to target assistance to particular populations. Depending on the targeting standard, it could be a cost-effective measure that achieves a significant increase in the program effect, while also effectively serving those most in need of assistance. As was found, the small ESP impact was due, in part, to the fact that a number of sample members were uninterested in ESP because they did not expect any earnings loss or were unwilling to lower their reservation wage further to obtain a supplement. Therefore, even if ESP had an impact for some participants, the program might have been unable to generate a big net impact for the participants as a whole. On the other hand, ESP had a large impact for certain groups of workers, such as those most likely to experience financial hardship. In such cases, the program's success may depend as much upon targeting the right population as it does upon its generosity.

One approach to implementing the targeting is profiling system, like that specified in the Worker Profiling and Reemployment Services (WPRS) mandated by the US Congress in 1993 (Eberts, 1997). A profiling system is a management tool that statistically identifies which workers should receive targeted assistance. In the context of ESP, a profiling system could be integrated by (1) developing a statistical model that estimates the need for displaced worker assistance, using a sample of individuals with records of reemployment experience; (2) collecting data on each individual's characteristics when he or she applies for the program; (3) applying the estimated model to each individual's characteristics to estimate the probability for assistance needs; and (4) classifying the target group based on the estimated probability for each individual. 
Finally, many policy analysts have argued that financial incentive programs can be made more effective if combined with other active labormarket policy measures (Lin et al., 1997). Thus combining ESP with other reemployment services, such as job-search assistance or vocational training, may be another policy option to increase ESP's impact, especially given that ESP influenced participants to consider a new type of job. Bloom et al. (1999) found that ESP had a significant impact on inducing program members to consider a new type of job. However, doing so often requires that workers attain new skills for which training might be needed. Also, such workers may have limited information about how to find a new type of job that is outside of their field. Given this, findings in my paper suggest that combining ESP with training or job-search assistance may encourage workers to consider new type of jobs in different industries or occupations, particularly for those whose job displacement is more costly.

\section{Bibliography}

Addison, J. T. and Portugal, P. 1989. Job Displacement, Relative Wage Changes, and Duration of Unemployment, Journal of Labor Economics, 7-3: 281 302.

Allison, P. D. 1982. Discrete-Time Methods for The Analysis of Event Histories, Sociological Methodology, 1982: 61 298 .

Allison, P. D. 1984. Event History Analysis: Regression for Longitudinal Event Data. SAGE Publications, Inc., Newbury Park, CA

Blank, R. and Card, D. E. 1991. Recent Trends in Insured and Uninsured Unemployment: Is There an Explanation? Quarterly Journal of Economics. November 1991: 1157 1 189.

Blau, D. M. and Robins, P. K. 1990. Job Search Outcome for the Employed and Unemployed, Journal of Political Economy, 98-3: 637 655.
Bloom, H. S. and Bloom, S. P. 1996. Research Design Issues and Options for Jobs-Plus, Unpublished paper, Manpower Demonstration Research Corporation.

Bloom, H. S., Fink, B., Lui-Gurr, S., Bancroft, W., and Tattrie, D. 1997. Implementing the Earnings Supplement Project: A Test of a Re-employment Incentive. Social Research and Demonstration Corporation, Ottawa, Canada.

Bloom, H. S., Schwartz, S., Lui-Gurr, S., and Lee, S. W. 1999. Testing a Re-employment Incentive for displaced Workers: The Earnings Supplement Project. Social Research Demonstration Corporation, Ottawa, Canada.

Bos, J. M. 1995. The Labor Market Value of Remedial Education. Ph. D. Dissertation, Robert F. Wagner Graduate School of Public Service, New York University.

Burgess, P. L. and Kingston, J. L. 1976. The Impact of Unemployment Insurance Benefits on Reemployment Success, Industrial and Labor Relations Review, 30-1: 25 -31.

Carrington, W. J. and Zaman, A. 1994. Interindustry Variation in the Costs of Job Displacement, Journal of Labor Economics, 12-2: 243 $\sim 275$.

Christofides, L. N. and McKenna, C. J. 1996. Unemployment Insurance and Job Duration in Canada, Journal of Labor Economics. 14-2: $286 \sim 312$

Classen, K. P. 1977. The Effect of Unemployment Insurance on the Duration of Unemployment and Subsequent Earnings, Industrial and Labor Relations Review. 30-4: 438 444.

Davidson, C. and Woodbury, S. A. 1994. Wage Subsidies for Dislocated Workers. Paper prepared for the Canadian Employment Research Forum Workshop on Displaced Workers and Public Policy Responses, December 23, 1994.

Davidson, C. and Woodbury, S. A. 1991. Effects of a Reemployment Bonus under Differing 
Benefit Entitlements, Unpublished Paper.

Dolton, P. and O'Neil, D. 1995. The Impact of

Restart on Reservation Wages and Long-Term Unemployment, Oxford Bulletin of Economics and Statistics, 57-4: $451 \sim 470$.

Eberts, R. W. 1997. The use of profiling to target services in state Welfare-to-work programs: An example of process and implementation, Unpublished working paper, W. E. Upjohn Institute for Employment Research.

Ehrenberg, R. G. and Oaxaca, R. L. 1976. Unemployment Insurance, Duration of Unemployment, and Subsequent Wage Gain, The American Economic Review, 66-5: $754 \sim 766$.

Fallick, B. C. 1996. A Review of The Recent Empirical Literature on Displace Workers, Industrial and Labor Relations Review. 50-1: $5 \sim 15$.

Feather, N.T . 1989. The Psychological Impact of Unemployment, Springer-Verlag New York Inc., New York, NY.

Feldstein, M. 1975. The Importance of Temporary Layoffs, Brookings Papers on Economic Activity, 4: $725 \sim 744$.

Feldstein, M. and Poterba, J. 1984. Unemployment Insurance and Reservation Wages, Journal of Public Economics, 23: $141 \sim 167$.

Fishe, R. P. H. 1982. Unemployment Insurance and The Reservation Wage of the Unemployed, The Review of Economics and Statistics, 64: $12 \sim 17$.

Gorter, D. and Gorter, C. 1993. The Relation Between Unemployment Benefits, The Reservation Wage and Search Duration, Oxford Bulletin of Economics and Statistics, 55-2: 199 $\sim 214$.

Green, D. A. and Craig Riddell, W. 1993. The Economic Effects of Unemployment Insurance in Canada: An Empirical Analysis of UI Disentitlement, Journal of Labor Economics, 11-1: S96 S147.

Greene, W. H. 1995. LIMDEP Version 7.0 User's
Manual., Bellport, NY., Econometric Software, Inc.

Greene, W. H. 1997. Econometric Analysis, $3^{\text {rd }}$ Ed. Prentice-Hall, Inc., Upper Saddle River, NJ.

Ham, J. C. and LaLonde, R. J. 1996. The Effect of Sample Selection and Initial Conditions in Duration Models: Evidence from Experimental Data on Training, Econometrica, 64-1: 175 $\sim 205$.

Ham, J. C. and Rea, S. A. 1987. Unemployment Insurance and Male Unemployment Duration in Canada, Journal of Labor Economics, 5-3: $325 \sim 353$.

Ham, J. C., Svejnar, J., and Terrell, K., 1998. Unemployment and the Social Safety Net During Transitions to a Market Economy: Evidence from the Czech and Slovak Republics, The American Economic Review, 88-5: $1117 \sim 1142$.

Hamermesh, D. S. 1987. The Cost of Worker Displacement, Quarterly Journal of Economics, 102: $51-75$.

Hao, L. 1997. Using a Multinomial Logit Specification to Model Two Interdependent Processes With an Empirical Application, Sociological Methods and Research, 26-1: 80 117.

Heckman, J. J. 1979. Sample Selection Bias As A Specification Error, Econometrica, 47-1: 153 $\sim 161$

Holen, A. 1977. Effects of Unemployment Insurance Entitlement on Duration and Job Search Outcome, Industrial and Labor Relations Review. 30-4: 445 450.

Holzer, H. J. 1986. Reservation Wages and Their Labor Market Effects for Black and White Male Youth, Journal of Human Resources, 21: $157 \sim 177$.

Howland, M. and Peterson, G. E. 1988. Labor Market Conditions and the Reemployment of Displaced Workers, Industrial and Labor Relations Review, 42-1: 109 122. 
Idson, T. L. and Valletta, R. G. 1996. Seniority, Sectoral Decline, and Employee Retention: An Analysis of Layoff Unemployment Spells, Journal of Labor Economics, 14-4: 654 676.

Jacobson, L., LaLonde, R., and Sullivan, D. 1993. The Costs of Worker Dislocation, W. E. Upjohn Institute for Employment Research. Kalamazoo, MI.

Johnson, T. R. and Klepinger, D. H. 1994. Experimental Evidence on Unemployment Insurance Work-Search Policies, Journal of Human Resources, 29-3: 695 717 .

Jones, S. R. G. 1988. The Relationship Between Unemployment Spells and Reservation Wages as a Test of Search Theory, Quarterly Journal of Economics, November 1988: 741 - 765.

Jones, S. R. G. 1989. Reservation Wages and The Cost of Unemployment, Economica, 56: 225 $\sim 246$.

Katz, L. F. and Meyer, B. D. 1990. Unemployment Insurance, Recall Expectations, and Unemployment Outcomes, The Quarterly Journal of Economics. November 1990, pp. 973 1002.

Kletzer, L. D. 1989. Returns to Seniority After Permanent Job Loss, American Economic Review, 79: 536 543.

Kletzer, L. D. 1992. Industry Wage Differentials and Wait Unemployment, Industrial Relations, 31-2: $250 \sim 269$.

Kletzer, L. G. 1991. Earnings after Job Displacement: Job Tenure, Industry, and Occupation. In Addison, J. T. ed., Job Displacement: Consequences and Implications for Policy, Wayne State University Press, Detroit, IL.

Kuhn, P. and Sweetman, A. 1998. Wage Loss Following Displacement: The Role of Union Coverage, Industrial and Labor Relations Review, 51-3: 384 400.

Lancaster, T. 1979. Econometric Methods for the Duration of Unemployment, Econometrica. 47-4: $939 \sim 956$.

Lancaster, T. and Chesher, A. 1983. An Econo- metric Analysis of Reservation Wages, Econometrica, 51-6: $1661 \sim 1676$.

Lin, W., Robins, P. K., Card, D., Harknett, K., and Lui-Gurr, S., 1998. When Financial Incentives Encourage Work: Complete 18-Month Findings from the Self Sufficiency Project. Social Research Demonstration Corporation, Ottawa, Canada.

Mare, R. D. 1994. Discrete-Time Bivariate Hazards With Unobserved Heterogeneity: A Partially Observed Contingency Table Approach, Sociological Methodology.

Melenberg, B. and van Soest, A. 1996. Parametric and Semiparametric Modeling of Vacation Expenditures, Journal of Applied Econometrics, 11: 59 - 76.

Meyer, B. D. 1990 . Unemployment Insurance and Unemployment Spells, Econometrica, 58-4: $757 \sim 782$.

Meyer, B. D. 1995. Lessons from the U.S. Unemployment Insurance Experiments, Journal of Economic Literature. 33: $91 \sim 131$.

Meyer, B. D. 1996. What Have We Learned from the Illinois Reemployment Bonus Experiment? Journal of Labor Economics, 14-1: 26 51.

Michalopoulos, C., Robins, P. K., and Card, D. 1999. When Financial Incentives Pay for Themselves: Early Findings from the SelfSufficiency Project's Applicant Study. Social Research Demonstration Corporation, Ottawa, Canada.

Moffit, R. 1985. Unemployment Insurance and The Distribution of Unemployment Spells, Journal of Econometrics, 28: 85 101.

Moffitt, R. and Nicholson, W. 1982. The Effect of Unemployment Insurance on Unemployment: The Case of Federal Supplemental Benefits, The Review of Economics and Statistics. 64-1: $1 \sim 11$.

Mortensen, D. T. 1986. Job Search and Labor Market Analysis, In Ashenfelter, O. and Layard. R. ed., Handbook of Labor Econo- 
mics, Vol. II, pp. 849 919 .

Mortensen, D. T. 1977. Unemployment Insurance and Job Search Decisions, Industrial and Labor Relations Review. 30-4: 505 517.

Narendranathan, W. and Nickell, S. 1985. Modeling The Process of Job Search, Journal of Econometrics, 28: 29 49 .

Neal, D. 1995. Industry-Specific Human Capital : Evidence from Displaced Workers, Journal of Labor Economics, 13-4: 653 - 677.

Paarsch, H. J. 1984. A Monte Carlo Comparison of Estimators for Censored Regression Models, Journal of Econometrics, Journal of Econometrics, 24: 197 213 .

Podgursky, M and Swaim, P. 1987. Job Displacement and Earnings Loss: Evidence From The Displaced Worker Survey, Industrial and Labor Relations Review, 41-1: 17 29.

Robertson, H. 1994. Wage Subsidies to Encourage the Hiring of Unemployment Insurance Claimants, Unpublished paper, Global Economics.

Singer, J. D. and Willett, J. B. 1993. It's About Time: Using Discrete-Time Survival Analysis to Study Duration and the Timing of Events, Journal of Educational Statistics. 18-2: 155 195.

Snower, D. J. 1997. Evaluating unemployment policies: What do the underlying theories tell us? In Snower, D. J. and de la Dehesa, B. ed., Unemployment policy: government options for the labour market, Cambridge University Press, Cambridge, Great Britain

Swaim P. L. and Podgursky, M. J. 1991. Displacement and Unemployment, In Addison, J. T. ed., Job Displacement: Consequences and Implications for Policy, Wayne State University Press, Detroit, IL.

Thomas, J. M. 1997. Public Employment Agencies and Unemployment Spells: Reconciling the Experimental and Nonexperimental Evidence, Industrial and Labor Relations Review, 50-4: $667 \sim 683$.

van den Berg, G. J. and van Ours, J. C. 1996. Unemployment Dynamics and Duration Dependence, Journal of Labor Economics. 14-1: $100 \sim 125$.

van Ophem, H. 1991. Wages, Nonwage Job Characteristics and The Search Behavior of Employees, The Review of Economics and Statistics, 73: 145 151.

Welch, F. 1977. What Have We Learned From Empirical Studies of Unemployment Insurance? Industrial and Labor Relations Review. 30-4: $451 \sim 461$. 